\title{
Arctic Ocean circulation and variability - advection and external forcing encounter constraints and local processes
}

\author{
B. Rudels ${ }^{1,2, *}$ \\ ${ }^{1}$ Department of Physics, University of Helsinki, Helsinki, Finland \\ ${ }^{2}$ Finnish Meteorological Institute, Helsinki, Finland \\ *Invited contribution by B. Rudels, recipient of the EGU Fridtjof Nansen Medal 2011.
}

Correspondence to: B. Rudels (bert.rudels@fmi.fi)

Received: 27 October 2011 - Published in Ocean Sci. Discuss.: 1 December 2011

Revised: 6 March 2012 - Accepted: 19 March 2012 - Published: 3 April 2012

\begin{abstract}
The first hydrographic data from the Arctic Ocean, the section from the Laptev Sea to the passage between Greenland and Svalbard obtained by Nansen on his drift with Fram 1893-1896, aptly illustrate the main features of Arctic Ocean oceanography and indicate possible processes active in transforming the water masses in the Arctic Ocean. Many, perhaps most, processes were identified already by Nansen, who put his mark on almost all subsequent research in the Arctic. Here we shall revisit some key questions and follow how our understanding has evolved from the early 20th century to present. What questions, if any, can now be regarded as solved and which remain still open? Five different but connected topics will be discussed: (1) The low salinity surface layer and the storage and export of freshwater. (2) The vertical heat transfer from the Atlantic water to sea ice and to the atmosphere. (3) The circulation and mixing of the two Atlantic inflow branches. (4) The formation and circulation of deep and bottom waters in the Arctic Ocean. (5) The exchanges through Fram Strait. Foci will be on the potential effects of increased freshwater input and reduced sea ice export on the freshwater storage and residence time in the Arctic Ocean, on the deep waters of the Makarov Basin, and on the circulation and relative importance of the two inflows, over the Barents Sea and through Fram Strait, for the distribution of heat in the intermediate layers of the Arctic Ocean.
\end{abstract}

\section{Introduction}

In the 19th century the high Arctic was an unknown part of the world. Was it an ocean or were still large landmasses to be found? Was it covered with ice or was open water present beyond the forbidding ice fields and hummocks that in the 16th and 17th centuries had prevented all expeditions to navigate the Northwest and the Northeast passages? Frobisher, Davis, Bylot and Baffin explored Davis Strait and Baffin Bay and Willem Barentsz the Barents Sea and the waters west of Svalbard in search of the Northwest and Northeast passages. Hudson tried to find both. All efforts were in vain, and eventually these navigational goals were replaced by hunting of whales and walruses. In the 17th century a Dutch whaling industry was established on Svalbard, and the northern North America was explored and exploited by British and French companies like the Hudson Bay Company.

In the 18th century Russian expeditions charted the Siberian coast and Vitus Bering explored the passage between North America and Asia, Bering Strait, but it was not until the beginning of the 19th century that renewed efforts were made to discover a navigational route north of North America. The expeditions of J. Ross (1818, 1829-1833) and W. E. Parry (1819-1820, 1821-1822, 1824-1825) did not succeed. J. Phipps (1773), W. Scoresby (1806), D. Buchan and J. Franklin (1816) and also Parry (1827) tried to sail north between Greenland and Svalbard but were stopped by the ice. Parry used sledges to go farther north and reached $82^{\circ} 45^{\prime} \mathrm{N}$ but had to return. The ice was drifting southward with a speed comparable to the progress over the ice and the 
northward advance was close to zero. The disappearance of the large expedition led by Franklin (1845) and the subsequent search for its fate added much information about the straits and islands in the now Canadian Arctic Archipelago but did not lead to the discovery of a navigable sea route connecting the North Atlantic to the North Pacific north of America. Ice was blocking the way.

In spite of these setbacks, a vision of an ice-free ocean beyond the pack ice arose in the late 18th and early part of the 19th century. M. Lomonosov, L. A. de Bougainville and S. Engel were among the first proponents of an ice-free polar ocean. Engel (1772) thought that since sea ice contains little salt only freshwater could freeze and once a ship passed through the girdle of low salinity water created by the river runoff, a navigable ocean would be found. D. Barrington, vice-president of the Royal Society in London, believed in an open Polar ocean and was promoting Phipps' expedition in 1773. The idea was getting stronger with time and in the mid 19th century it found its principal spokesman in the German geographer Augustus Petermann. Petermann's arguments for an ice free polar ocean were partly that open water had been observed north of Siberia also in winter beyond the frozen coastal areas, but also that the ocean currents, especially the Gulf Stream, were transporting warm water northward to the Arctic. This heat would be sufficient to prevent ice to form and keep an ocean close to the North Pole free of ice (Petermann, 1865) (Fig. 1).

The most favourable routes to penetrate northward into this area of open water would be to follow the warm currents, the Norwegian Atlantic Current and the West Spitsbergen Current between Greenland and Svalbard. A second possibility would be east of Svalbard, where a part of the Norwegian Atlantic Current flows into the Barents Sea and then continues north. Petermann was involved in the planning of the German North pole expeditions led by C. Koldeway $(1868,1869-1870)$ and was also giving advice to the Austrian Tegetthoff expedition (1872-1874) led by K. Weyprecht and J. Payer. Both these expeditions ended by ships getting caught in the ice and abandoned. During the same period Great Britain and the United States were, after the search for Franklin, who had disappeared in an attempt to navigate the Northwest Passage, trying to reach the open Polar ocean west of Greenland. The expeditions by E. K. Kane (1853-1855), I. Hayes (1860-1861), C. Hall (1871-1873) and G. Nares (1875-1876) penetrated north between Greenland and Ellesmere Island, the Nares Strait, into the Arctic Ocean to finally be stopped by the ice.

The ongoing expeditions gradually reduced the extent of the unknown areas, where an ice-free polar ocean could possibly exist, and in 1879 the vessel Jeanette commanded by G. Delong sailed north to Bering Strait to look for A. E. Nordenskiöld and Wega. However, as Delong reached Bering Strait, Wega had already completed the Northeast Passage and passed south into the North Pacific. Delong continued northward through Bering Strait to try to reach the North
Pole from the Pacific sector. Jeanette got caught in the ice the first winter and then again the second winter and the ship had to be abandoned in 1881. A few members of the crew made it back to safety but Delong was not among those.

Three years after the wreckage of Jeanette, parts from the ship were found at Julianehåb on the southwest coast of Greenland. This discovery indicated that there must exist a rapid transport of ice, and perhaps water, across the Arctic Ocean from Siberia to the opening between Greenland and Svalbard and then along the east coast of Greenland to Kap Farvel and northward along the west coast of Greenland. To Fridtjof Nansen this discovery also showed a way to enter the inner, unknown, part of the Arctic Ocean. A ship, strong enough to withstand the press of the ice, or so constructed that it was squeezed upwards rather than pressed down by the ice, could be frozen into and then drift with the ice across the Polar sea, perhaps passing the North Pole, and then exit between Greenland and Svalbard.

Nansen's idea, although criticized at the time, eventually found support and the Norwegian ship builder Colin Archer constructed Fram, a ship that should be able to withstand the ice press, and in 1893 Fram with Nansen as expedition leader and Otto Sverdrup as captain sailed along the Siberian coast eastward to the East Siberian Sea, where the ship entered the pack ice. Three years later, in 1896, Fram came loose of the ice north of Svalbard and steamed towards Troms $\varnothing$, arriving a few weeks after Nansen, who together with Hjalmar Johansen had tried to reach the North Pole with dog-sledges and skis but had to abandon the attempt and finally overwinter on Franz Josef Land, where they were found by the British explorer F. Jackson (Fig. 2a).

The voyage of Fram gave the first information of the inner part of the Polar sea - the Arctic Ocean. It was a deep ocean and it was ice covered (Nansen, 1902). The ice was found to drift to the right of the wind, a feature that Nansen believed was caused by the rotation of the Earth and which later led to the formulation of the theory of wind driven ocean currents by Ekman (1905).

The hydrographic observations showed a temperature maximum between $150 \mathrm{~m}$ and $250 \mathrm{~m}$ with temperatures above $0^{\circ} \mathrm{C}$, indicating that Atlantic water was present in the Arctic Ocean just as Petermann had expected. However, the Atlantic water was separated from the ice by a low salinity, cold surface layer. This layer had such low density that even if it were cooled to freezing temperature, it would not convect into the Atlantic water but remain above. The low salinity layer thus acted as a barrier that prevented the heat stored in the Atlantic water to reach and melt the ice. The influence of the river runoff was not confined to the coastal areas but extended over the entire Arctic Ocean (Fig. 2b).

Finally it was found that the salinity increased towards the bottom, forming a high salinity, cold bottom water. Nansen's interpretation of these high bottom salinities was that during ice formation over the shallow shelf areas brine was released and sank towards the bottom, where it accumulated during 


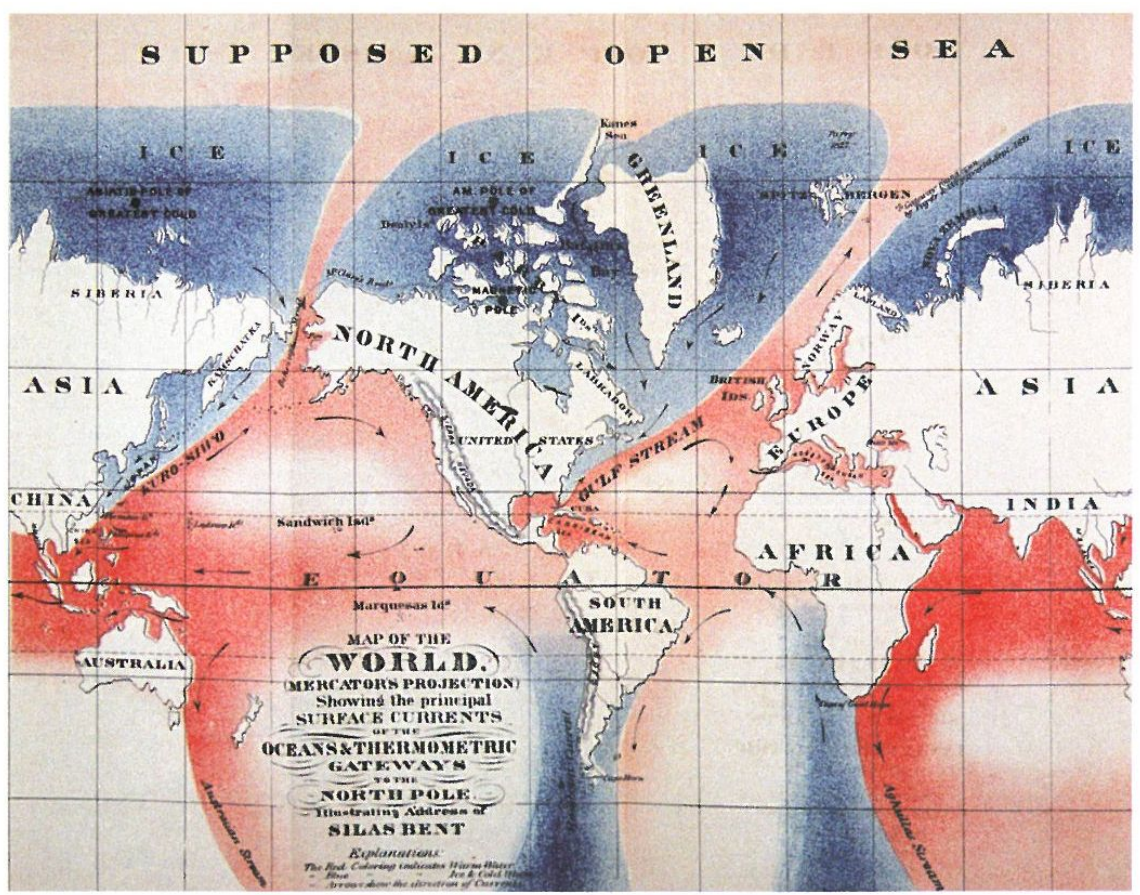

Fig. 1. A map by Silas Bent, 1872, showing the warm ocean currents and their assumed impact on the ice cover of the Arctic Ocean. From Hayes (2003).

winter gradually increasing in density. Eventually this dense shelf bottom water crossed the shelf break and sank into the deep Arctic Ocean, creating the cold, saline bottom water (Nansen, 1906). The accuracy of the salinity measurements on the Fram salinity samples was later questioned, and after making observations of the Arctic Ocean deep and bottom water north of Svalbard, Nansen concluded that the salinities measured on the Fram samples were too high, and proposed that the deep water in the Arctic Ocean derived from the open ocean deep convection area in the central Greenland Sea (Nansen, 1915).

After the drift of Fram, intense oceanographic studies were also conducted in the Greenland Sea and the Barents Sea (e.g. Knipowisch, 1905; Nansen, 1906; Helland-Hansen and Nansen, 1909) and the Northwest Passage was finally navigated by Roald Amundsen with Gjøa 1903-1905. Fram under Sverdrup made a second voyage to the Canadian Arctic Archipelago 1898-1902 and explored several of its islands and straits, and the Russian Hydrographic Expedition of the Arctic Ocean 1910-1915 charted the northern sea route (the Northeast Passage) and discovered Severnaya Zemlya. After the First World War, Amundsen tried to reach the North Pole from the Pacific on Maud 1918-1925, but Maud was trapped by the ice in the East Siberian Sea and did not cross the shelf break into the deep basin. The studies on tides and long waves by H. U. Sverdrup (1925) and on sea ice by F. Malmgren (1927) were the main oceanographic achievements from this expedition.
In the 1930s the Soviet icebreaker Sedov, getting caught in the ice, involuntarily duplicated the drift of Fram. Another, rather spectacular, attempt to penetrate into the interior of the Arctic Ocean was made in 1931, when a discarded US submarine, Nautilus, was taken to the waters west and north of Svalbard. When Nautilus reached the ice, it was discovered that the diving rudders did not function. The submarine could not dive and no subsurface voyage to the North Pole could be made. It should take $27 \mathrm{yr}$ before another Nautilus surfaced at the North Pole. However, some oceanographic stations were taken in the deep Arctic Ocean north of Svalbard. A more successful attempt to reach the North pole was made in May 1937, when the Soviet Union established its first ice station North Pole -1 led by I. Papanin at $89.4^{\circ} \mathrm{N}, 78.7^{\circ} \mathrm{E}$. The station drifted quickly southward and passed through the strait between Greenland and Svalbard, now called Fram Strait after the Fram drift, and the four members were picked up by the Soviet icebreakers Taymyr and Murman in the Greenland Sea in February 1938.

The observations from Nautilus and from North Pole -1 complemented the picture of the Arctic Ocean given by the Fram voyage. It was a deep ocean with a warm Atlantic layer deriving from the inflow through Fram Strait in the West Spitsbergen Current and cold bottom water with temperatures increasing with increasing distance from the Greenland Sea, supporting Nansen's revised view of the deep water ventilation with the deep water source for the Arctic Ocean and the Nordic Seas in the Greenland Sea (Fig. 3). 

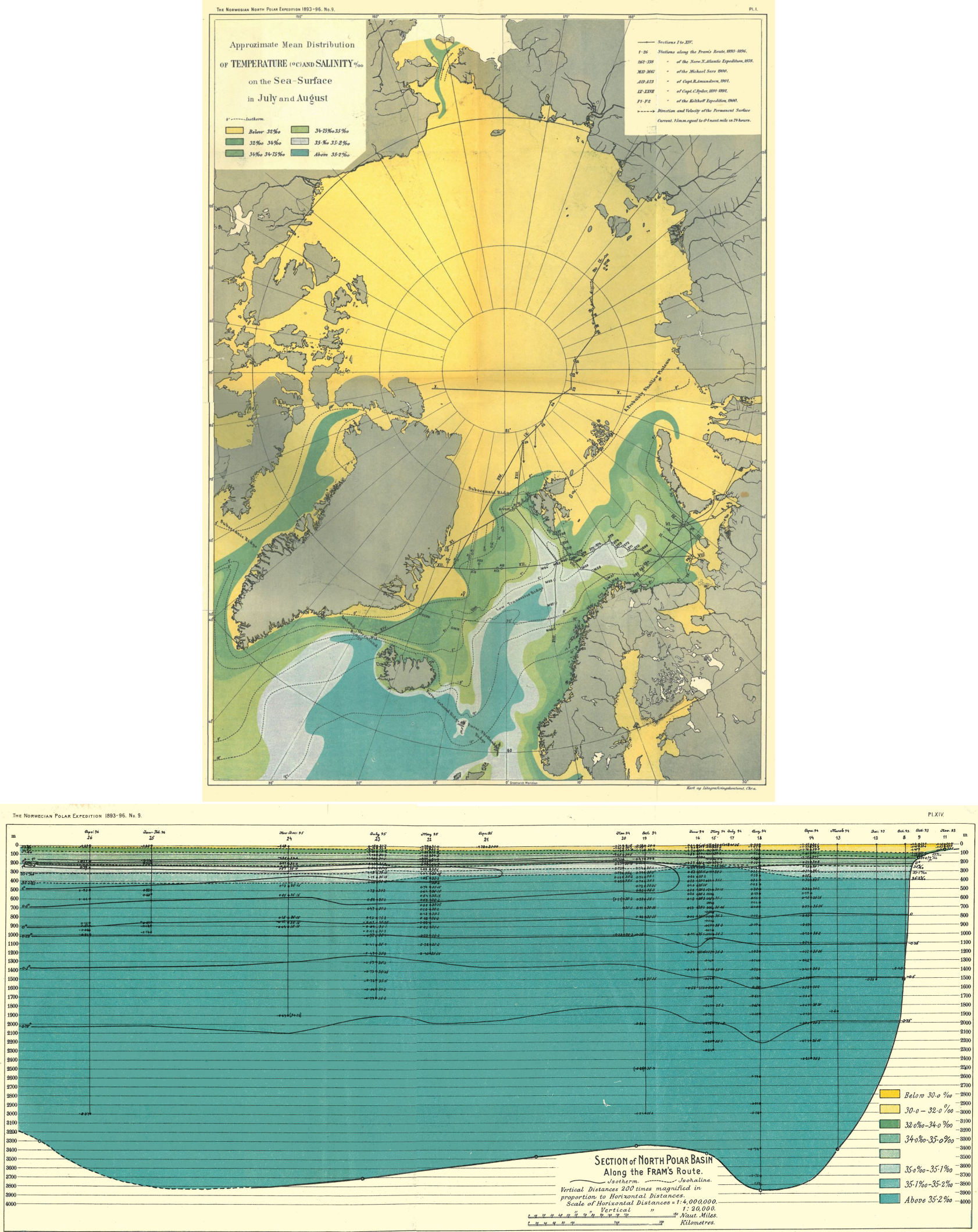

Fig. 2. (a) Map of the Arctic Mediterranean showing the drift of Fram and the surface salinity (colours) and the surface isoterms (dotted lines). From Nansen (1902). (b) Temperature and salinity section based on the hydrographic observations made from Fram during the drift from the Laptev Sea to Fram Strait. From Nansen (1902). 


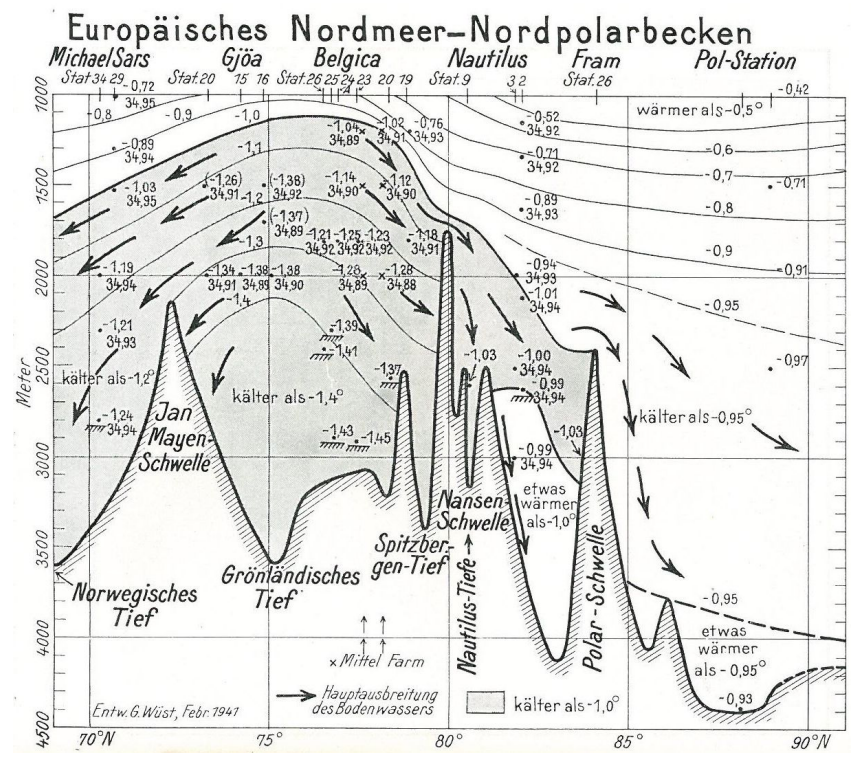

Fig. 3. A temperature section from the Nordic Seas into the Arctic Ocean compiled by Wüst from available observations taken between the 1880s and the 1930s. From Wüst (1941).

After World War II more ice stations were established, by the Soviet Union and by the United States and Canada, and the airborne activity of the Soviet Union continued in spring each year extending over almost the entire Arctic Ocean, gradually increasing the number of hydrographic stations. From these observations a more detailed picture of the bathymetry, the water masses and the circulation of the Arctic Ocean was emerging (Fig. 4). In the following sections we shall concentrate on five themes present almost at the beginning of the scientific study of the Arctic Ocean and see how our understanding of these themes has evolved, if at all, from the first attempts made by Nansen and others in the beginning of the last century. The themes considered are:

1. The low salinity surface layer and the storage and export of freshwater.

2. The heat flux between the Atlantic layer, the sea ice and the atmosphere.

3. The circulation of the Atlantic water.

4. The formation and circulation of deep and bottom water.

5. Exchanges through Fram Strait.

\section{The low salinity surface layer and the storage and export of freshwater}

The Arctic Ocean is a small ocean. Its coastline, and hence its drainage area, is large compared to its area. Precipitation

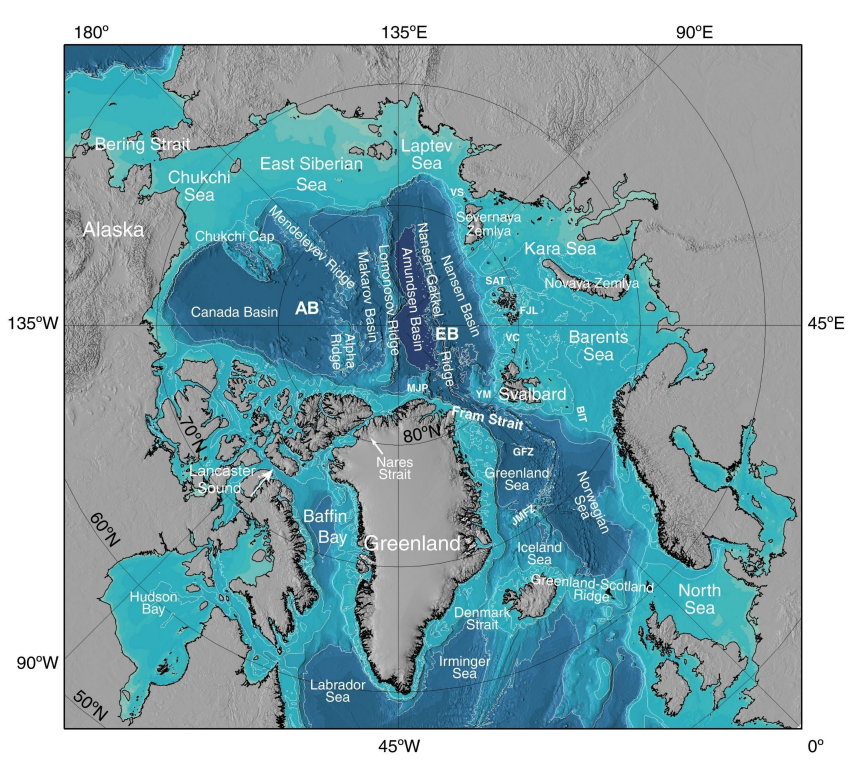

Fig. 4. Bathymetry of the Arctic Ocean (IBCAO) (Jakobsson et al., 2008), map from Rudels et al. (2011). AB (Amerasian Basin), EB (Eurasian Basin), BIT (Bear Island Trough), VC, (Victoria Channel), FJL (Franz Josef Land), SAT (St. Anna trough), VS (Vilkiltskiy Strait), YM (Yermak Plateau), MJP (Morris Jesup Plateau), GFZ (Greenland Fracture Zone), JMFZ (Jan Mayen Fracture Zone).

over the ocean is larger than evaporation, adding to the freshwater input. This has created the observed strong stability in the upper layer and allows ice to form in winter and to survive the seasonal melting in summer. Freshwater is also supplied by the low salinity inflow through Bering Strait. This inflow is driven by a higher sea level in the North Pacific compared to the North Atlantic (Stigebrandt, 1984), which ultimately arises because of the atmospheric water vapour transfer from the North Atlantic to the North Pacific across the Isthmus of Panama (Weyl, 1968). However, the transport has a strong seasonal cycle, being weaker in winter due to persisting northerly winds that oppose the inflow (Coachman and Aagaard, 1988). A smaller advective contribution to the positive freshwater balance of the Arctic Ocean is provided by the Norwegian Coastal Current that carries low salinity water from the Baltic Sea and from the Norwegian coast into the Barents Sea and then to the deep Arctic Ocean via the Siberian shelf seas.

The freshwater balance is maintained by the export of sea ice and by the outflow of low salinity surface water through Fram Strait and through the shallow and narrow passages in the Canadian Arctic Archipelago. The ice export is largely driven by the wind fields and only to a smaller degree by the ocean currents and is therefore subject to large temporal variations (Dickson et al., 2000). The transport of liquid freshwater, by contrast, occurs primarily as rotationally controlled buoyant boundary currents (Wadhams et al., 1979; Stigebrandt, 1981). The currents have the coast to the right 
(in the Northern Hemisphere) and flow above a denser water mass assumed at rest, which reaches the surface away from the coast. This approach thus ignores the contributions from the barotropic component of the boundary current.

Following Rudels (2010), we assume a vertical coast and that the transport in the upper layer is given by Werenskiold's formula (Werenskiold, 1935);

$M=\frac{\left(\rho_{\mathrm{A}}-\rho_{1}\right) g H_{1}^{2}}{2 \rho_{\mathrm{A}} f}=M_{\mathrm{A}}+F$

Here $H_{1}$ is the depth of the upper layer at the coast, $\rho_{\mathrm{A}}$ and $\rho_{1}$ the density of the lower and upper layer, respectively, $g$ the acceleration of gravity and $f$ the Coriolis parameter. $F$ is the liquid freshwater export (freshwater input - ice export) and $M_{\mathrm{A}}$ the amount of lower layer water entrained into and exported in the upper layer. The sea ice salinity is taken to be zero.

In cold ocean waters the density is almost exclusively determined by the salinity and we can apply a simplified equation of state:

$\rho=\rho_{\mathrm{f}}(1+\beta S)$

where $\rho_{\mathrm{f}}$ is the density of freshwater, $\beta$ the coefficient of salt contraction and $S$ the salinity. The reduced gravity $g^{\prime}$ can then be written as:

$g \frac{\left(\rho_{\mathrm{A}}-\rho_{1}\right)}{\rho_{\mathrm{A}}}=g^{\prime} \approx g \beta\left(S_{\mathrm{A}}-S_{1}\right)$

where $S_{\mathrm{A}}$ and $S_{1}$ are the salinity of the lower (Atlantic) layer and the upper layer and $\rho_{\mathrm{f}} / \rho_{\mathrm{A}} \approx 1$ (e.g. Stigebrandt, 1981).

The export of low salinity surface water then depends upon the number of effective passages, the depth of the upper layer and the salinity difference between the layers in the passages. Of the three passages in the Canadian Arctic Archipelago that connect the Arctic Ocean to Baffin Bay only two, Lancaster Sound and Nares Strait, are wide enough to transport with full capacity (Fig. 4). Assuming that the depth of the upper layer and the salinity of the upper and lower layers are the same in all passages, the salinity in the upper layer can be written as:

$S_{1}=\frac{M_{\mathrm{A}} S_{\mathrm{A}}}{\left(F+M_{\mathrm{A}}\right)}$

and the freshwater storage $m$ (in metres) in the Arctic Ocean water column becomes:

$m=\frac{\left(S_{\mathrm{A}}-S_{1}\right) H_{1}}{S_{\mathrm{A}}}$

If $S_{1}$ is eliminated between Eqs. (4) and (5) we obtain;

$\left(M_{\mathrm{A}}+F\right)^{2}=\frac{3 g F S_{\mathrm{A}} H_{1}^{2}}{2 f}$ and

$m=\frac{F H_{1}}{\left(M_{\mathrm{A}}+F\right)}$

The freshwater storage can then be written as;

$m=\left(\frac{2 f F}{3 g \beta S_{\mathrm{A}}}\right)^{1 / 2}$

$m$ only depends upon the freshwater input and ice export and the salinity in the lower layer, the number of outlets and on $f$ and $g$. The width of the boundary current is approximately given by the baroclinic Rossby radius $\mathrm{Ro}=\sqrt{ } g^{\prime} H_{1} / f$, which becomes:

$$
\begin{aligned}
\mathrm{Ro} & =\frac{\left(g \beta\left(S_{\mathrm{A}}-S_{1}\right) H_{1}\right)^{1 / 2}}{f}=\frac{\left(g \beta S_{\mathrm{A}} m\right)^{1 / 2}}{f} \\
& =\left(\frac{2 g \beta S_{\mathrm{A}} F}{3 f^{3}}\right)^{1 / 4}
\end{aligned}
$$

and also only depends upon the freshwater storage and ultimately on the freshwater input and the ice export.

Applying reasonably realistic values (e.g. Serreze et al., 2006; Dickson et al., 2007) for the freshwater input ( $0.29 \mathrm{~Sv})$ and the ice export $(0.09 \mathrm{~Sv})$, the liquid freshwater export $\mathrm{F}$ becomes $0.2 \mathrm{~Sv}\left(1 \mathrm{~Sv}=1 \times 10^{6} \mathrm{~m}^{3} \mathrm{~s}^{-1}\right)$. Setting the Atlantic water salinity $S_{\mathrm{A}}$ to 35 and using $g=9.83 \mathrm{~m} \mathrm{~s}^{-2}$ and $f=1.4 \times 10 \mathrm{~s}^{-1}$ the freshwater storage $m$ becomes $8.25 \mathrm{~m}$ and the baroclinic Rossby radius Ro $\sim 10 \mathrm{~km}$ (Rudels, 2010). The freshwater storage estimated by Serreze et al. (2006) was $74000 \mathrm{~km}^{3}$, which spread over the entire Arctic Ocean $\left(10 \times 10^{6} \mathrm{~km}^{2}\right)$ is $7.4 \mathrm{~m}$, fairly close to the value obtained here. The width of the boundary currents of $10 \mathrm{~km}$ shows that both Lancaster Sound and Nares Strait are wide enough to transport with full capacity.

If the upper layer depth is different in the three channels, the outflow will be somewhat larger and the mean depth (and storage) of the freshwater layer in the Arctic Ocean must be slightly smaller to achieve a freshwater balance. In the situation that there would be no net ice formation and no sea ice export, presently estimated to $0.09 \mathrm{~Sv}$, the freshwater export $\mathrm{F}$ would rise to $0.29 \mathrm{~Sv}$, and the freshwater storage has to increase to $10.1 \mathrm{~m}$ before the export balances the input. In general, the freshwater storage increases as $\sqrt{ } F$, while the residence time decreases as $1 / \sqrt{ } F$. If only the storage in the central Arctic Ocean, with an area of $5 \times 10^{6} \mathrm{~km}^{2}$, is considered, the residence time for the liquid freshwater is presently about $13 \mathrm{yr}$, while the storage time for sea ice with a thickness of $2 \mathrm{~m}$ would be around $7 \mathrm{yr}$.

Much of the exchange through Fram Strait, especially the inflow, takes place in barotropic streams following the bottom contours and through barotropic eddies (Schauer et al., 2008). Although the barotropic transports contribute significantly to the exchanges, perhaps providing the major part of the volume transports, the barotropic velocities are still considerably smaller than the baroclinic velocities in the upper 
low salinity water. Adding a barotropic component to the shallow, low salinity surface layer should then not increase, or decrease, the freshwater outflow by any large amount.

Another assumption is that the density (salinity) of the lower layer is the same in all channels. This is not the case. The salinity of the lower layer in Fram Strait is close to 35, which is used here, but the lower layer in the Canadian Arctic Archipelago, represented by the upper layer in Baffin Bay, has a salinity of 33.7 (Riis-Karstensen, 1936). The situation in the Baffin Bay and Canadian Arctic Archipelago is more complicated since there are two, actually three, control sections, two in the Archipelago and one in Davis Strait. This fact can be used to better determine the transports of volume and freshwater west of Greenland (Rudels, 1986a, 2011).

In recent years the accumulation of freshwater in the Beaufort Gyre has increased to above $25 \mathrm{~m}$ (Proshutinsky et al., 2010; Rabe et al., 2011). This increased storage is caused by the anti-cyclonic atmospheric circulation over the Beaufort Sea, which induces an Ekman transport towards the centre of the gyre. At the same time low salinity water is removed from, or rather, does not as easily flow towards, the outflow channels. The depth of the freshwater layer then diminishes in the straits and the outflow becomes weaker, supporting the accumulation in the Beaufort gyre. This accumulation in the Beaufort Gyre is not confined to the situation with a strong anti-cyclonal wind forcing. In the second, more cyclonical, of the two wind driven circulation modes described by Proshutinsky and Johnson (1997), runoff from the Siberian rivers is not transported directly to Fram Strait but becomes forced into the Amerasian Basin and eventually becomes trapped in the Beaufort Gyre (Morison et al., 2012).

This situation is likely to prevail as long as the wind field is capable of retaining the freshwater and increasing the freshwater storage. Once the wind forcing relaxes, the low salinity upper water will spread out and if the deepening of the upper layer travel as a Kelvin wave along the northern shelf and slope of the Canadian Arctic Archipelago and Greenland the low salinity outflow will increase after about a year. No rapid, large increase is expected because of the rotational control. It would more likely be a longer period of enhanced outflow. An increase of the freshwater storage of $25 \%$, which is comparable to the total melting of the sea ice, could initially increase the outflow by almost a third. After that the outflow declines toward the equilibrium transport, removing the excess freshwater in about $10 \mathrm{yr}$. A large advected freshwater anomaly like that observed in the late 1960 s would rather be caused by a sudden increase in the ice export forced by anomalous atmospheric conditions.

The atmospheric forcing and the wind driven component of the Arctic Ocean circulation have here been given scant attention. The wind forcing does not just drive the ice and collect the low salinity upper layers in the Beaufort Gyre. It also influences the water mass and density distribution in the water column and thus contributes to the geostrophically balanced circulation. To what extent the wind, as the two circu- lation modes discussed by Proshutinsky and Johnson (1997), or the thermohaline forcing controls the density field and the velocities and transports in the Arctic Ocean is not addressed in this work, which concentrates on the effects of density changes rather than on the density distribution.

In the discussion above essentially only two contributions have been considered, the freshwater input and the underlying Atlantic water, which is assumed to be entrained into the upper low salinity layer. However, the Arctic Ocean is not just the northernmost bay of the North Atlantic. It is also an, albeit restricted, channel that connects the North Pacific to the North Atlantic. The inflow through Bering Strait brings not only freshwater but transports low salinity water from the North Pacific to the North Atlantic driven by the higher sea level in the North Pacific (Stigebrandt, 1984). This difference in sea level could also force some of the less saline upper water out of the Arctic Ocean and into the North Atlantic, most likely through the Canadian Arctic Archipelago. The freshwater storage in the Arctic Ocean estimated here would then be too high, since the upper layer outflow has been assumed to be driven only by the baroclinic pressure gradient generated by the freshwater input, including the freshwater supplied by the Bering Strait inflow. The freshwater transport due to a low salinity outflow forced by an imposed sea level difference between the Arctic Ocean and the North Atlantic is not taken into account. An attempt to introduce an additional "barotropic" sea level correction for the Canadian Arctic Archipelago - Baffin Bay system was made by Rudels (2011), who arrived at an additional freshwater export of $0.042 \mathrm{~Sv}$ and an increase of the volume transport by $0.8 \mathrm{~Sv}$ in the upper layer.

\section{The heat flux between the Atlantic layer, the sea ice and the atmosphere}

One important effect of the large freshwater supply to the Arctic Ocean is the resulting strong stability that isolates the entering Atlantic water from the atmosphere and insulates the ice cover from the heat transported by the Atlantic Ocean current system from the tropics and subtropics to the Arctic Mediterranean Sea and the Arctic Ocean. This phenomenon prevents the formation of the open Polar ocean that in the 19th century was speculated to exist. In the 1970s, in the light of a possible diversion of one or two of the Siberian rivers from the Arctic Ocean to central Asia for irrigation purposes, the same question arose: will the reduced stability lead to stronger vertical heat flux from the Atlantic layer, thinning and perhaps removing of the ice cover? (Aagaard and Coachman, 1975). The same question is debated today in light of the observed recent reduction in the minimum sea ice extent and sea ice thickness (e.g. Polyakov et al., 2012).

The large transports of Atlantic water into the Arctic Ocean through Fram Strait determined by direct current measurements in the West Spitsbergen Current enhanced 
the importance of this question (Aagaard et al., 1973; Aagaard and Greisman, 1975). In the early 1980s the Fram Strait Project (FSP) was initiated to determine the exchanges between the Nordic Seas and the Arctic Ocean through Fram Strait. The transports of Atlantic water and heat through Fram Strait were also a focus for the oceanography programme on the Swedish Ymer-80 expedition, one of the first scientific ice breaker expeditions to the Arctic Ocean. CTD sections extending across the entire Fram Strait essentially started with Ymer in 1980 (Rudels, 1987) and were eventually being taken yearly as more powerful research icebreakers like R/V Polarstern and ice strengthened research vessels like RV Lance came into operation. At the peak of the FSP in 1984-1985, a current meter array covering the entire strait was deployed by Geophysical Institute in Bergen, the University of Hamburg, the University of Washington with the support of the Norwegian Polar Research Institute (Foldvik et al., 1988).

The FSP coincided with the international Marginal Ice Zone Experiment (MIZEX), which was devoted to studying the interactions between ocean, ice and atmosphere occurring as sea ice meets the warmer waters in Fram Strait and the Barents Sea (MIZEX East) as well as in the Bering Sea and Chukchi Sea (MIZEX West). After FSP the exchanges through Fram Strait have been studied in the EU projects VEINS (Variability of Exchanges In the Northern Seas) (1997-2000), ASOF-N (Arctic-Subarctic Ocean Fluxes) (2003-2006), DAMOCLES (Developing of Arctic Modelling and Observational Capabilities for Long-term Environmental Studies) (2005-2010), where one of the main components has been the maintenance of a current meter array of 16 moorings across the strait by the Alfred Wegener Institute in Bremerhaven and Norwegian Polar Institute in Troms $\varnothing$ and the occupation of yearly hydrographic sections across the strait as the moorings have been recovered and redeployed.

The Atlantic water extends to the surface as the West Spitsbergen Current enters the Arctic Ocean. There it encounters, and melts, sea ice and the upper part of the Atlantic water becomes transformed into a less saline, cold surface layer. The Atlantic water does not sink beneath the Polar water but its upper part becomes a less dense polar water mass (Rudels et al., 1996). One question then arises: How much of the heat lost by the Atlantic water is used to melt ice and how much goes to the atmosphere? This partition has some relevance, when the impact of the Atlantic water on the ice cover shall be evaluated.

The salinity of the upper layer north of Svalbard is usually around 34.2-34.3. If the temperatures and salinity of the underlying Atlantic water are taken as the initial temperature and salinity of the upper layer, the amount of melted ice can, assuming that all lost heat goes to ice melt, be estimated from;

$$
S_{1}=\frac{S_{\mathrm{A}}}{\left(1+c L^{-1}\left(T_{\mathrm{A}}-T_{1}\right)\right)}
$$

where $S_{1}$ is the salinity and $T_{1}$ the temperature of the upper layer and $S_{\mathrm{A}}$ is the salinity of the Atlantic water, $c=$ $4000 \mathrm{~J} \mathrm{~kg}^{-1}$ degree $^{-1}$ is the heat capacity of seawater and $L=335000 \mathrm{~J} \mathrm{~kg}^{-1}$ the latent heat of melting. With $S_{\mathrm{A}}=$ 35 and $T_{\mathrm{A}}=3.1$ and $T_{1}$ equal to the freezing temperature $-1.9^{\circ} \mathrm{C}$ giving $\left(T_{\mathrm{A}}-T_{1}\right)=5^{\circ} \mathrm{C}, S_{1}$ becomes $\approx 33$, clearly lower than the observed value.

The higher salinity then indicates that only a fraction, and a minor fraction, goes to ice melt (Fig. 5). The larger part is lost to the atmosphere. Rudels et al. (1999a) and Rudels (2010) explored the situation, when sea ice melts on warmer water under freezing conditions using a KatoPhillips energy balance model (Kato and Phillips, 1969). The entrainment velocity $w_{\mathrm{e}}$ then becomes;

$$
\begin{gathered}
w_{\mathrm{e}}=\frac{2 n_{\mathrm{o}} u_{*}^{3}}{g\left(\beta\left(S_{\mathrm{A}}-S_{1}\right)-\alpha\left(T_{\mathrm{A}}-T_{1}\right)\right) H_{1}} \\
-\frac{\varepsilon B}{g\left(\beta\left(S_{\mathrm{A}}-S_{1}\right)-\alpha\left(T_{\mathrm{A}}-T_{1}\right)\right)}
\end{gathered}
$$

Here $u_{*}$ is the friction velocity, $n_{\mathrm{o}}$ a constant $\approx 1.5$ and $\varepsilon$ a parameter set to 1 when positive buoyancy is added and to 0.05 when the buoyancy input is negative (Stigebrandt, 1981). $\alpha$ and $\beta$ are the coefficients of heat expansion and salt contraction, respectively.

As the Atlantic water cools by melting sea ice and by giving up heat to the atmosphere, two buoyancy inputs are generated, one positive due to ice melt and one negative due to cooling, and the positive buoyancy input depends on the fraction, $\phi$, of heat going to ice melt.

$$
\begin{aligned}
B & =g\left\{\left(w_{\mathrm{e}} \frac{\phi c}{L} \Delta T_{\mathrm{A}} \beta S_{\mathrm{A}}+\frac{\phi c}{L} \beta S_{\mathrm{A}} H_{1} \frac{d\left(\Delta T_{\mathrm{A}}\right)}{\mathrm{d} t}\right)\right. \\
& \left.-\left(w_{\mathrm{e}} \alpha \Delta T_{\mathrm{A}}+H_{1} \alpha \frac{d\left(\Delta T_{\mathrm{A}}\right)}{\mathrm{d} t}\right)\right\}
\end{aligned}
$$

$B$ is the total buoyancy flux and $\Delta T_{\mathrm{A}}=\left(T_{\mathrm{A}}-T_{1}\right)$. The first bracket is the positive contribution due to ice melt and the second bracket the negative contribution due to cooling. Within the brackets the first term represents the cooling of the entrained water to the mixed layer temperature and the second term the reduction of the mixed layer temperature. When the upper layer has reached freezing temperature the second terms become zero. Both buoyancy inputs influence the entrainment velocity, which will be given by:

$$
\begin{aligned}
w_{\mathrm{e}} & =\frac{n_{\mathrm{o}} u_{*}^{3}\left(1+\phi c L^{-1} \Delta T_{\mathrm{A}}\right)}{g \Delta T_{\mathrm{A}}\left(\phi c L^{-1} \beta S_{\mathrm{A}}-\alpha\left(1+\phi c L^{-1} \Delta T_{\mathrm{A}}\right)\right) H_{1}} \\
& -\frac{H_{1}}{2 \Delta T_{\mathrm{A}}} \frac{d\left(\Delta T_{\mathrm{A}}\right)}{\mathrm{d} t}
\end{aligned}
$$



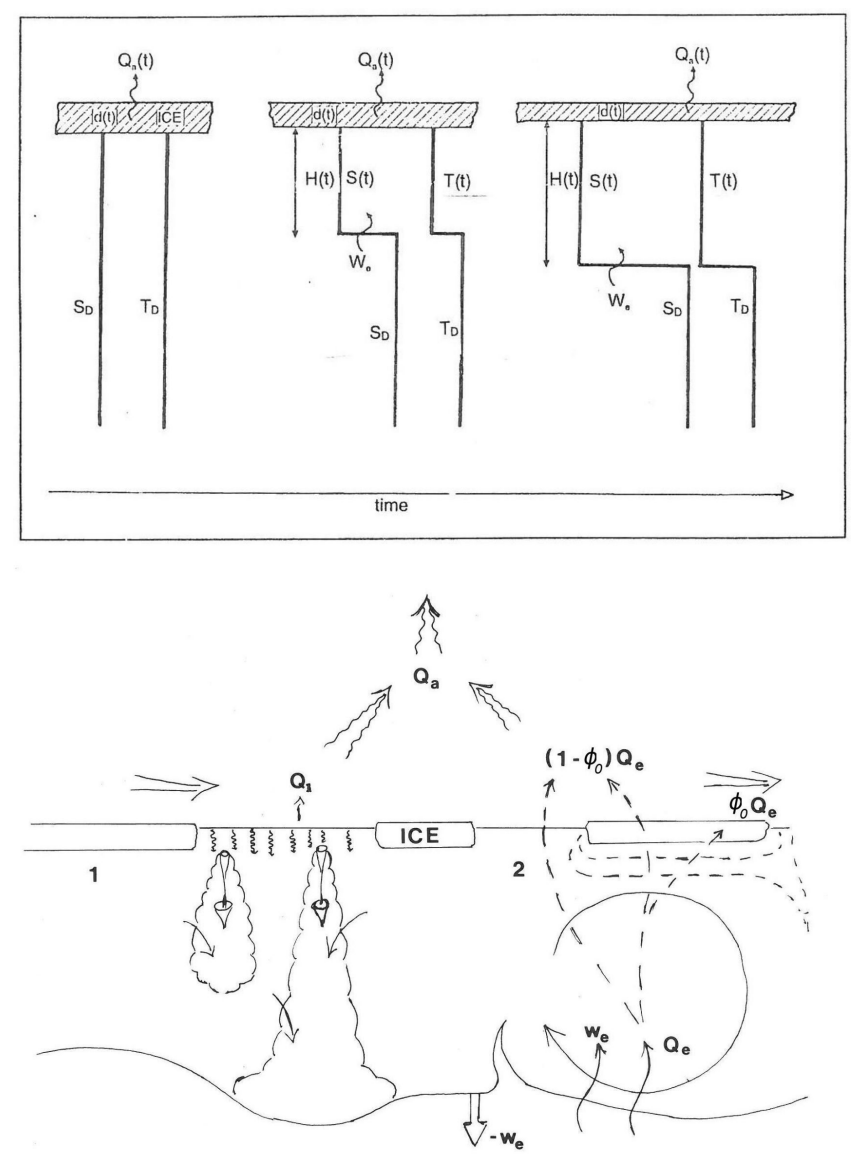

Fig. 5. Upper panel: the evolution of the upper layer, when warm water encounters sea ice under freezing conditions. From Rudels et al., 1999a. Lower Panel: schematics showing oceanic heat loss under freezing conditions and in the presence of sea ice. From Rudels (1995).

To proceed we make the crucial assumption that the heat flux to ice melt is a minimum (Rudels et al., 1999a; Rudels, 2010). This keeps the density step between the created low salinity surface layer and the underlying Atlantic water small and allows for a more rapid transfer of heat from the Atlantic water to the upper layer and to ice melt and to the atmosphere. The entrainment velocity is directly related to the heat flux $Q$, which can be written as;

$$
\begin{aligned}
Q & =G\left\{u_{*}^{3}, \Delta T_{\mathrm{A}}, t, \frac{d\left(\Delta T_{\mathrm{A}}\right)}{\mathrm{d} t}\right\} \\
\cdot & \frac{1}{\sqrt{\phi c L^{-1} \beta S_{\mathrm{A}}-\alpha\left(1+\phi c L^{-1} \Delta T_{\mathrm{A}}\right)}}
\end{aligned}
$$

where $G$ is a factor that does not depend upon $\phi$. The fraction $\phi_{0}$, giving the minimum ice melt, is then determined from;

$\frac{d\left(\phi Q^{\prime}\right)}{d \phi}=0$, with $Q^{\prime}=\left(\phi c L^{-1} \beta S_{\mathrm{A}}-\alpha\left(1+\phi c L^{-1} \Delta T_{\mathrm{A}}\right)\right)^{-1 / 2}$ which leads to;

$\phi_{\mathrm{o}}=\frac{2 \alpha L}{c\left(\beta S_{\mathrm{A}}-\alpha \Delta_{\mathrm{A}} T\right)} \approx \frac{2 \alpha L}{c \beta S_{\mathrm{A}}}$

The upper layer salinity then becomes;

$S_{1}=\frac{S_{\mathrm{A}}}{\left(1+\frac{\phi_{0} c \Delta T_{\mathrm{A}}}{L}\right)} \approx \frac{S_{\mathrm{A}}}{\left(1+\frac{2 \alpha \Delta T_{\mathrm{A}}}{\beta S_{\mathrm{A}}}\right)}$

Using $\alpha=0.6 \times 10^{-4}$, corresponding roughly to the value at $T=0.6^{\circ} \mathrm{C}$, and $\beta=8 \times 10^{-4}, S_{1}$ becomes $\sim 34.3$, which should be compared to 33.1 found above for the case when all heat goes to ice melt. This is the minimum salinity. Once freezing temperature is reached in the upper layer the entrained heat is not sufficient to fulfil the heat flux to the atmosphere and to ice melt and new ice starts to form. This is considered to occur simultaneously to the ice melt (Rudels et al., 1999a) (Fig. 5). Since $\alpha$ increases with increasing temperatures, warm water will supply more and a larger fraction of heat to ice melt than colder water.

North of Svalbard the energy driving the entrainment from the Atlantic water to the upper layer is supplied by the wind. As the Atlantic water is advected farther and eastward into the Arctic Ocean in the boundary current along the Eurasian continental slope, its upper part becomes stratified by seasonal ice melt in summer and in winter ice formation and brine rejection generate haline convection. This homogenizes the upper layer down to the thermocline above the Atlantic water. The $\theta S$ curves ( $\theta$ is the potential temperature) that during the wind mixed phase were straight lines from the mixed layer to the temperature maximum of the Atlantic water become curved, indicating that the brine enriched water penetrates into and cools the upper part of the thermocline (Rudels et al., 1996; Kikuchi et al., 2004) (Fig. 6). Convection is not a good stirrer and its intensity depends on the freezing. Should it bring warm water towards the ice the freezing would diminish and the entrainment would cease. The ice cover is thus in a sense self-protected against convectively driven heat flux from below (Martinson and Steele, 2001).

The second inflow branch from the Nordic Seas to the Arctic Ocean passes over the Barents Sea. It is cooled extensively in the southwestern part of the Barents Sea and also becomes freshened by net precipitation. The temperature and salinity of the core of the Atlantic water become lower than those of the Fram Strait inflow before it encounters sea ice. This should, according to Eq. (16), lead to less heat going to ice melt and more heat going to the atmosphere, because $\alpha$ decreases with decreasing temperature. This effect dominates over the reduction in Atlantic water salinity and the salinity of the upper, transformed, layer (Eq. 17) becomes higher in the Barents Sea branch than in the Fram Strait branch. The two inflows meet north of the Kara Sea as the main part of the Barents Sea inflow enters the Arctic Ocean 

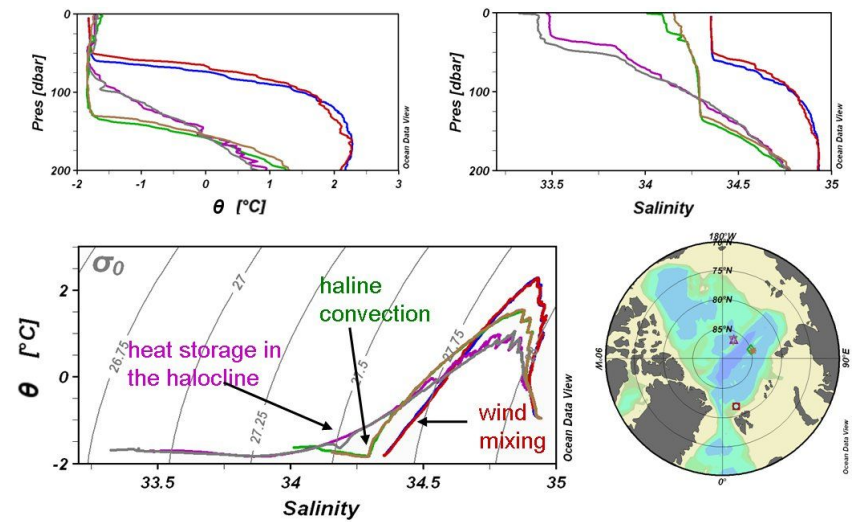

Fig. 6. Potential temperature and salinity profiles and $\theta S$ curves from different parts of the Arctic Ocean showing the effects of wind mixing and heat entrained and lost to ice melt and to the atmosphere at the entrance to the Arctic Ocean, of haline convection bringing cold water into and cooling the thermocline in the Nansen Basin, and of heat mixed from below into and stored in halocline in the interior of the Arctic Ocean The ODV software (Schlitzer, 2012) has been used to create diagrams in this and most other figures.

in the St. Anna Trough. On a north-south section taken over the shelf and slope by Polarstern in 2007 and crossing the two inflow branches the $\theta S$ curves from the two branches clearly show that the upper part of the Barents Sea branch has a higher salinity than the warm Fram Strait branch (Fig. 7).

It is also evident that the salinity at the base of the upper layer, which indicates the salinity of the mixed layer in winter, in both branches better corresponds to the salinity obtained from Eq. (17) than the situation when all heat goes to ice melt (Eq. 10). The lower salinity seen along the freezing point line reflects the summer melting caused by the incoming short wave solar radiation.

North of the Laptev Sea the boundary current and the two branches become overrun by low salinity shelf water comprising the major part of the river runoff from $\mathrm{Ob}$, Yenisey and Lena that crosses the shelf break. After this the cooling and ice formation in winter only homogenize the water column down the base of the less saline shelf water layer that becomes the Polar Mixed Layer (PML). The upper parts of the two inflow branches become isolated from the surface processes and are transformed to cold halocline waters that further insulate the sea ice cover from the heat stored in the Atlantic layer. The mixing and entrainment that do occur will only bring more saline but cold halocline water into the mixed layer and little heat is supplied from below. The heat from the Atlantic layer is instead trapped in the halocline, where the temperature gradually increases (Fig. 6).

The winter convection and the homogenization of the PML is in summer identified by an upper temperature minimum that is the remnant of the convection being eroded by the radiative heating above and by mixing with the somewhat warmer halocline below, where the heat lost vertically up-
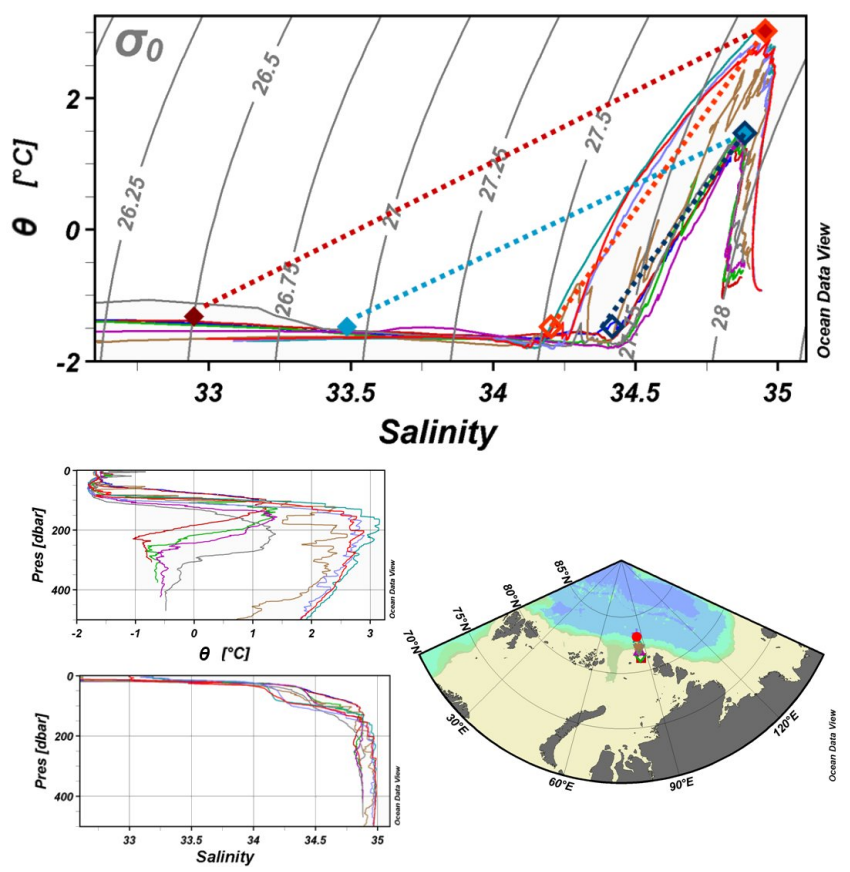

Fig. 7. Potential temperature and salinity profiles and $\theta S$ diagrams showing the difference of the winter mixed layers and the Atlantic cores of the Fram Strait branch (red) and the Barents Sea branch (blue). In spite of having a cooler and less saline Atlantic layer the winter mixed layer of the Barents Sea branch, created by stirring melt water into the upper part of the Atlantic water, is more saline than that of the Fram Strait branch. The filled diamonds indicate the salinity of the mixed layer if all oceanic heat is going to ice melt, the open diamonds the salinity if minimum heat is going to ice melt based on the temperature and salinity of the Atlantic water.

ward by the Atlantic layer is stored (Fig. 8). Only on the slope in the western Nansen Basin, where no halocline is present and the Atlantic layer is brought close to the sea surface, does the temperature minimum become completely eroded. This indicates that heat can be transferred from the Atlantic layer to the mixed layer and the ice also in summer (Rudels, 2010). In the rest of the Arctic Ocean the heat transferred upward from the Atlantic layer will be trapped in the halocline.

The heat flux appears to be stronger in the Barents Sea branch, possibly due to enhanced mixing over the continental slope. The colder Fram Strait branch is farther away from the slope and eventually supplies the halocline in the Amundsen, Makarov and northern Canada basins, while the Barents Sea branch remains at the slope and passes between the Chukchi Sea and the Chukchi Cap into the southern Canada Basin (Rudels et al., 2004; Shimada et al., 2005).

Between the Laptev Sea and the Canada Basin, shelf water is added to the Arctic Ocean as well as Pacific water from Bering Strait via the Chukchi Sea. Most of these waters are less dense than the Laptev Sea outflow and contribute additional layers to the upper part of the water column. Some 

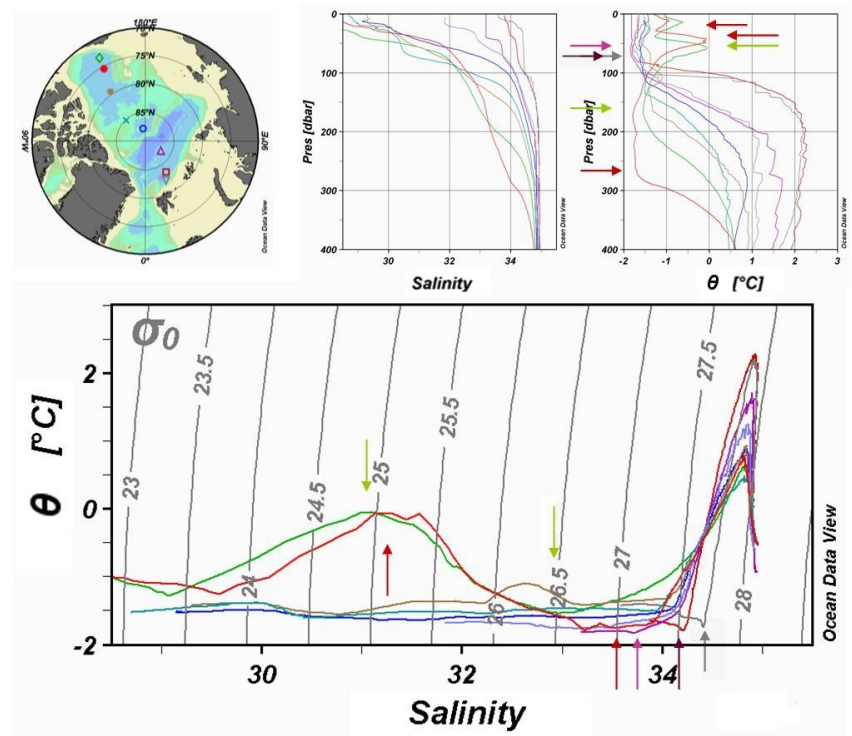

Fig. 8. Halocline features in the Arctic Ocean. The grey, dark red and magenta arrows indicate the temperature minimum created by the winter homogenization. The red arrows show on one station, the Near Surface Temperature Maximum (NSTM) due to seasonal heating (Jackson et al., 2010), the temperature maximum due to the inflow of Bering Strait Summer Water (BSSW) and a temperature minimum due to the presence of an (isolated?) eddy of Fram Strait branch lower halocline water. The green arrows show the temperature maximum of the BSSW and the temperature minimum of the Bering Sea Winter Water (BSWW). Note that the NSTM is present also on the green station and that the temperature minimum of the winter homogenization is present above the BSSW maximum on both the green and the red station.

water masses like the Bering Sea Summer Water (BSSW) and Bering Sea Winter Water (BSWW) (Coachman and Barnes, 1961) and other brine enriched shelf waters from the Chukchi Sea (Jones and Anderson, 1986) are dense enough to penetrate between the PML and the halocline, making further contributions to the halocline and changing the initial, denser halocline with salinity of $\sim 34.2$ into the lower halocline (Fig. 8). The circulation of the halocline waters is summarized in Fig. 9.

\section{The circulation of the Atlantic water}

The uppermost part of the water column follows the wind driven ice motion and circulates anticyclonally in the Beaufort Gyre in the southern Canada Basin and also participates in the transpolar drift from Siberia towards Fram Strait. By contrast the Atlantic water moves cyclonically around the deep Arctic Ocean basin. This motion was first deduced from the decrease in temperature of the Atlantic core in the different parts of the Arctic Ocean. It is highest in the Nansen Basin north of Svalbard and lowest in the Canada Basin and north of Greenland, indicating a cyclonic flow and a gradual

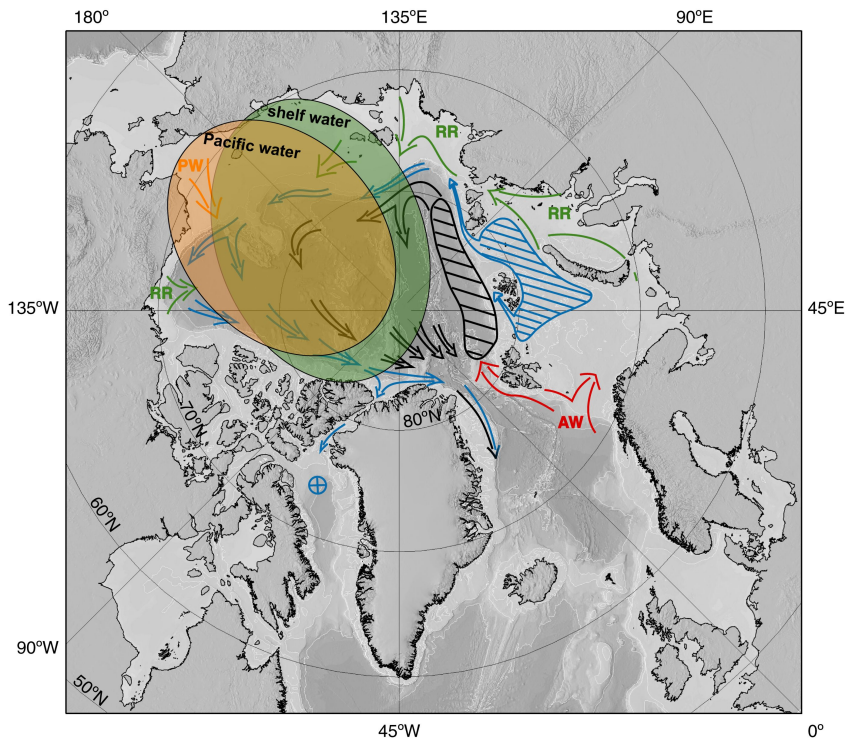

Fig. 9. Schematics showing the formation and circulation of the waters feeding the Fram Strait branch and the Barents Sea branch lower haloclines and how they become covered by less saline shelf water and Pacific water. Based on Rudels et al. (2004), figure from Rudels (2009).

cooling of the Atlantic layer (Timofeyev, 1960; Coachman and Barnes, 1963).

In 1991 the icebreaker Oden took a hydrographic section from the central Nansen Basin across the Gakkel Ridge, the Amundsen Basin, the Lomonosov Ridge into the Makarov Basin (Anderson et al., 1994; Rudels et al., 1994). On the section two distinct temperature fronts were found, one over the Gakkel Ridge and one over the Lomonosov Ridge. At the same time extensive layers of temperature and salinity inversions were observed. These layers, being identified in $\theta S$ space on several stations, suggested mixing between two water masses, one warm and saline closer to the continental slope and the other colder and fresher nearer the Lomonosov Ridge. The intrusive layers were found over a large depth range and the transports of the two involved water masses should be of about equal strength. The origin of the warmer end member is the inflow through Fram Strait and the most likely source for the colder end member is the inflow from the Norwegian Sea over the Barents Sea to the Arctic Ocean. The Barents Sea branch enters the Arctic Ocean in the St. Anna Trough and should be found closer to the continental slope north of the Kara and Laptev seas.

The Oden section did not extend to the continental slope east of the St. Anna Trough and the properties of this inflow had to be hypothetical. Furthermore, since the intrusions were observed in the central part of the basins with the warmest water in the Nansen Basin and the colder, less saline water in the Amundsen Basin, this would imply that a part of the boundary current leaves the continental slope and enters 
the interior Eurasian Basin, forming a return flow towards Fram Strait. The intrusions did not seem to change substantially between the main Oden section and the sections taken closer to Fram Strait, indicating that they were no longer expanding laterally but being advected as fossil structures with the main flow. At the Lomonosov Ridge the Atlantic core was somewhat warmer and this was tentatively explained by a more rapid return flow along the Lomonosov Ridge (Rudels et al., 1994).

There was also a strong contrast between the Atlantic and intermediate waters on the two sides of the Lomonosov Ridge. The Atlantic water was much colder and less saline, while the intermediate water was warmer and more saline in the Makarov Basin than in the Amundsen Basin. This suggested that water on the Makarov Basin side was moving from Greenland towards Siberia after it had travelled around the Makarov Basin. Kikuchi et al. (2005) noticed that in 2004 there was almost no temperature difference in the Atlantic layer across the Lomonosov Ridge and attributed this to the circulation of the warm Atlantic water inflow pulse reported by Quadfasel et al. (1991), which then would have moved around the Makarov Basin and be flowing along the Lomonosov Ridge towards Siberia.

The change in water mass properties could be due to shelfslope convection, where initially cold, saline plumes, created by brine rejection on the shelves, are sinking down the slope, entering and cooling the Atlantic water and also bypassing the Atlantic layer entraining warmer water and displacing it to deeper levels. Following a scheme proposed by Rudels (1986b), a plume entrainment model was applied to describe the changes in the Atlantic and intermediate waters in the Amerasian Basin and to determine the amount and the properties of the shelf water needed to explain the observed changes in the water column (Rudels et al., 1994) (Fig. 10).

The postulated colder and less saline inflow from the Barents Sea via the St. Anna Trough was observed north of the Laptev Sea in 1993 (Schauer et al., 1997) and intense interactions between the two inflow branches were seen on the slope north of Severnaya Zemlya in 1995 (Rudels et al., 2000). Nutrient observations from the Atlantic and intermediate waters north of Greenland also suggested that the coldest Atlantic water closest to Greenland actually represented a separate stream that had passed along the continental slope through the Canada Basin and was returning along the North American and Greenland continental slope to Fram Strait (Rudels et al., 1994).

In the 1990s the first reports and studies of changes in the Atlantic water temperature were published (Quadfasel et al., 1991; Carmack et al., 1995; Morison et al., 1998) and subsequent expeditions and studies could follow the propagation of the warm inflow pulse. Its movement largely confirmed the proposed circulation scheme for the Atlantic water (Fig. 11). Some additional loops were found (Smith et al., 1999; Smethie et al., 2000) but also the spreading of the warmer water into the southern Canada Basin ap-
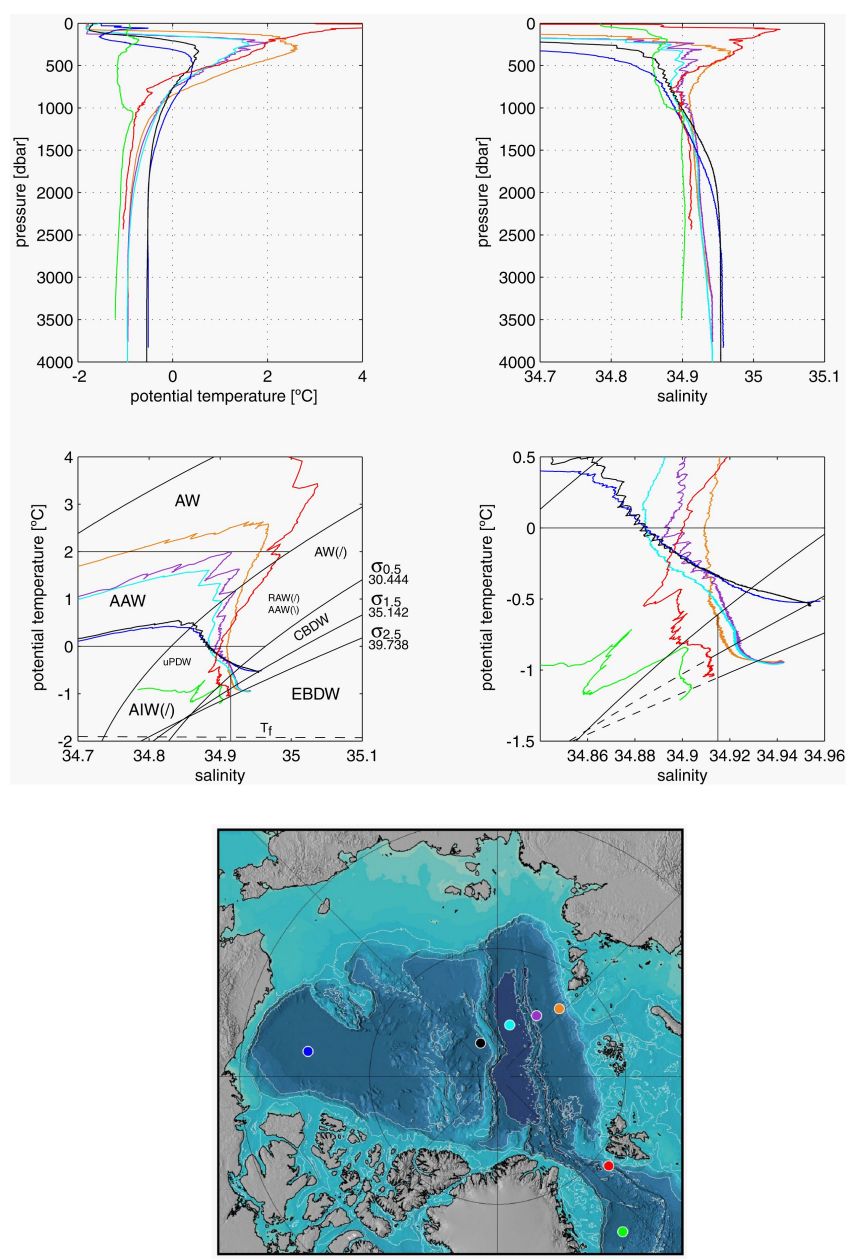

Fig. 10. Potential temperature and salinity profiles and $\theta S$ curves showing the characteristics of some water masses in the Arctic Mediterranean. Green station, Greenland Sea, red station, Fram Strait, orange station, Nansen Basin slope, magenta station, Gakkel Ridge, cyan station, Amundsen Basin, black station, Makarov Basin, blue station Canada Basin. AW (Atlantic Water), AAW (Arctic Atlantic Water), RAW (Recirculating Atlantic Water), uPDW (upper Polar Deep Water), AIW (Arctic Intermediate Water), CBDW (Canadian Basin Deep Water), EBDW (Eurasian Basin Deep Water), NDW (Nordic Seas Deep Water). (/) indicates unstable stratification in either temperature or salinity, and $(\backslash)$ indicates stable stratification in both components. From Rudels (2009).

peared uncertain. Did it enter the Canada Basin between the Chukchi Cap and the Chukchi continental slope or did it move around the Chukchi Cap (Shimada et al., 2004)? Was the heat transported into the Canada Basin as thermohaline intrusions (Walsh and Carmack, 2003; McLaughlin et al., 2009) and did it circulate anticyclonally around the Beaufort Gyre (McLaughlin et al., 2009) as was previously suggested by Coachman and Barnes (1963) and Newton and Coachman (1974)? Coachman and Barnes (1963) and Newton and Coachman (1974), however, report that a cyclonal circulation along the continental slope appeared to be present also 


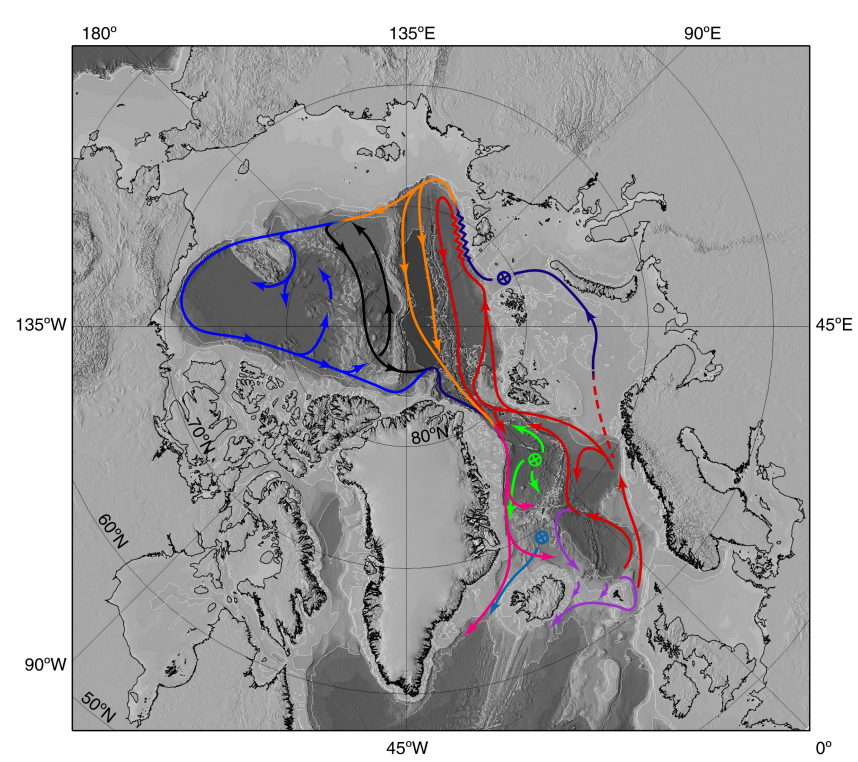

Fig. 11. Circulation of the Atlantic and intermediate waters in the Arctic Mediterranean Sea showing the mixing area north of Severnaya Zemlya and the gradual changes of the properties of the Atlantic water. Based on Rudels et al. (1994), figure from Rudels et al. (2011).

in the Canada Basin (Fig. 11). This makes the name "the Arctic Circumpolar Boundary Current" used by Rudels et al. (1999b) still valid. It also became clear that much of the cooling of the Atlantic water and the warming of the intermediate water must occur north of the Chukchi shelf, since the water on the East Siberian Sea shelf had too low salinity to produce water dense enough to sink below the PML (Aagaard et al., 1981).

Several warm Atlantic water pulses have later been observed and followed upstream in the Norwegian Sea and downstream in the boundary current along the Eurasian continental slope, along the Lomonosov Ridge and into the Amundsen Basin (Swift et al., 1997; Polyakov et al., 2005, 2011). The suggested return flow in the northern Nansen Basin and over the Gakkel Ridge has, however, largely been questioned or ignored.

The area north of the Laptev Sea is where the largest changes in the Atlantic water properties take place. The core of the Atlantic water does not appear to cool significantly in the boundary current between the western Barents Sea $\left(30^{\circ} \mathrm{E}\right)$ and the eastern Kara Sea $\left(90^{\circ} \mathrm{E}\right)$ and smooth profiles in temperature and salinity are seen in the core of the Fram Strait branch (Fig. 12). On the Kara Sea slope the inner part of the boundary current comprises the Barents Sea inflow branch that is located at the $400 \mathrm{~m}$ isobath and the potential for mixing between the two branches is present and partly takes place. At $126^{\circ} \mathrm{E}$, north of the Laptev Sea, the smooth central core of the Fram Strait branch has disappeared. The temperature of the temperature maximum has decreased by
$1{ }^{\circ} \mathrm{C}$ and the salinity has been reduced by 0.05 . Strong intrusions are also present in the Atlantic layer and in the intermediate water below. The temperature is lower at the slope and in the interior of the basin and lateral temperature and salinity maxima are still present close to the slope (Fig. 13). At $90^{\circ} \mathrm{E}$, on the basin side of the Fram Strait branch, similar cooling and freshening of the Atlantic and intermediate waters are observed and intrusions indicate lateral mixing with the less saline and colder Barents Sea branch (Fig. 12).

There are four processes that can explain the strong cooling and freshening of the Atlantic layer that occur north of the Laptev Sea. (1) Heat loss to the atmosphere and to ice melt. The difficulty with this explanation is to introduce freshwater into the core of the Atlantic layer since melt water, due to its low density, would likely be trapped in the Polar Mixed Layer. (2) Lateral mixing between the two inflow branches, leading to the formation of intrusive layers and to lower temperature and salinity in the Fram Strait branch. The heat remains in the core but the temperature is reduced because of the mixing and volume increase due to the incorporation of Barents Sea branch water. (3) Cooling and freshening by shelf-slope convection that brings colder, less saline water into the Atlantic layer and also convects denser water that bypasses the Atlantic layer, entrains warmer water and brings it downwards to deeper levels. Heat is displaced vertically but stays in the water column. (4) The Fram Strait branch is imbedded between Barents Sea branch water at the slope and in the interior, which suggests that the Barents Sea branch water partly leaves the slope and enters the interior of the Nansen Basin. The Fram Strait branch would then have to return with the Barents Sea branch water towards Fram Strait within the Nansen Basin and most of its heat would not pass eastward of the section along $126^{\circ} \mathrm{E}$ and thus not enter the Amundsen Basin and cross the Lomonosov Ridge. This return flow then also carries the intrusive layers between the two branches towards Fram Strait.

This implies that most of the Atlantic layer in the Arctic Ocean beyond the Nansen Basin is supplied by the Barents Sea branch. By comparing the $\theta S$ structure of the different basins with that of the Barents Sea branch, this does not appear inconceivable (Fig. 14). However, there are no watertight boundaries in the ocean and intermittently some water from the Fram Strait branch enters the Barents Sea branch and crosses the Lomonosov Ridge. The warm pulse traced since the 1990s could be such an instance.

Another caveat is that the Barents Sea branch properties considered here are those observed on the shelf-slope at $90^{\circ} \mathrm{E}$. This may not be the properties that the Barents Sea branch had, when it left the Barents Sea and entered the St. Anna Trough. Recent studies indicate that most heat of the Atlantic water entering the Barents Sea is lost locally and the mean temperature of the Atlantic water leaving the Barents Sea is about $0{ }^{\circ} \mathrm{C}$ (Gammelsrød et al., 2010). However, most of the surface water is at the freezing point and the deeper layers have temperatures between $-1.0^{\circ} \mathrm{C}$ and 

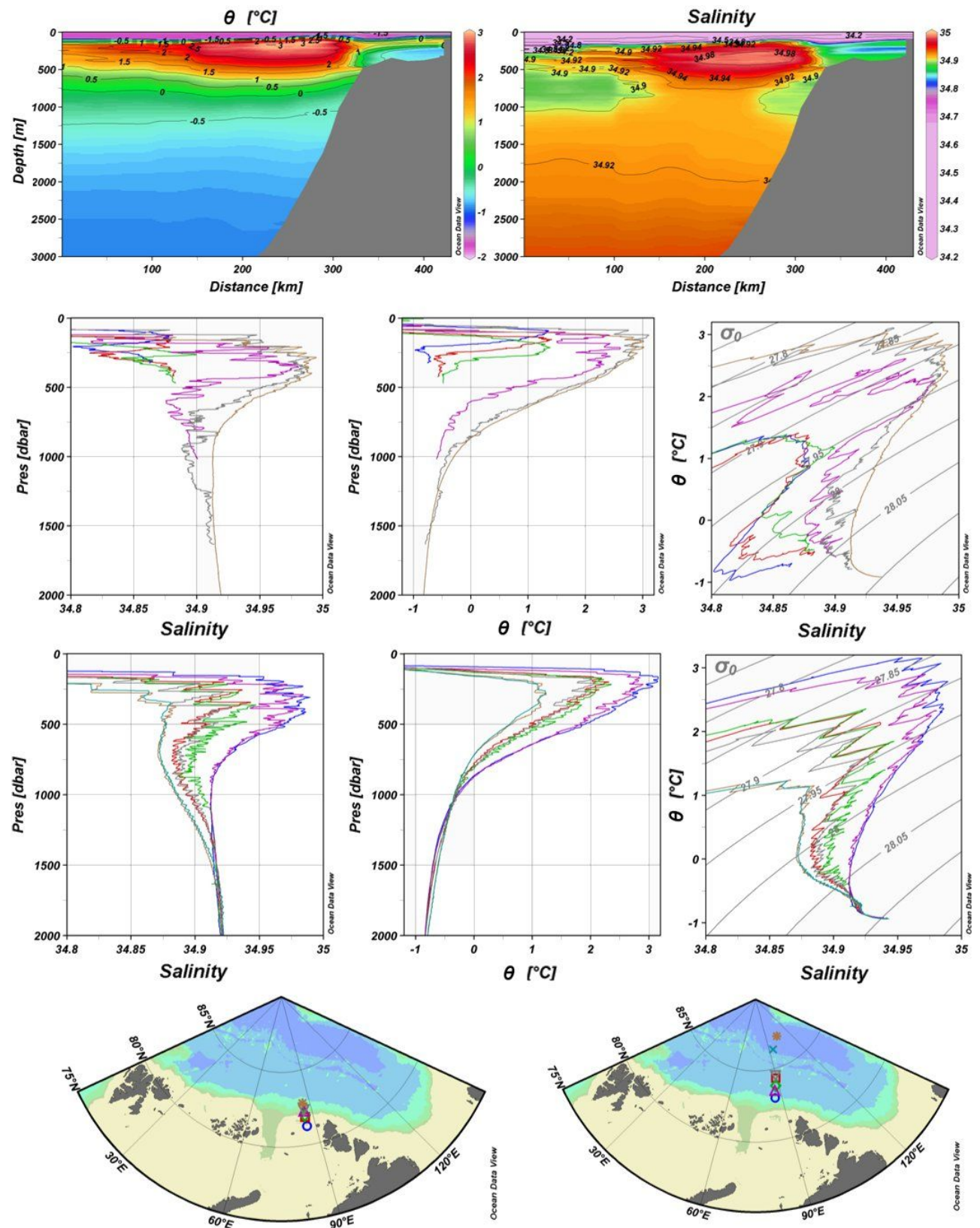

Fig. 12. Water masses mixing and interleaving in the Nansen Basin north of the eastern Kara Sea. Upper panel: temperature and salinity sections from the shelf to the Gakkel Ridge showing the warm saline Fram Strait Atlantic core and the cooler and less saline Barents Sea branch water on the slope and also on the basin side of the warm core. Upper centre panel: potential temperature and salinity profiles and $\theta S$ curves from the slope showing the characteristics of the two branches and the mixing between them across the front. Lower centre panel: potential temperature and salinity profiles and $\theta S$ curves from the deep basin showing the interleaving structures and different fronts. Lower panel: maps showing the positions of the stations. Data from Polarstern 2007.

$-0.5^{\circ} \mathrm{C}$. A remaining core of Atlantic water with temperatures around $1{ }^{\circ} \mathrm{C}$ could be present and still give an average outflow temperature of $0^{\circ} \mathrm{C}$.

It is also possible that Fram Strait branch water that enters the St. Anna Trough from the Arctic Ocean mixes with the Barents Sea branch in the trough and becomes incorporated in the Barents Sea branch, adding warmer Atlantic water, and then flows high on the slope eastward within the Barents Sea branch. In such a way the Fram Strait branch would contribute to the Atlantic layer also beyond the Nansen Basin. 

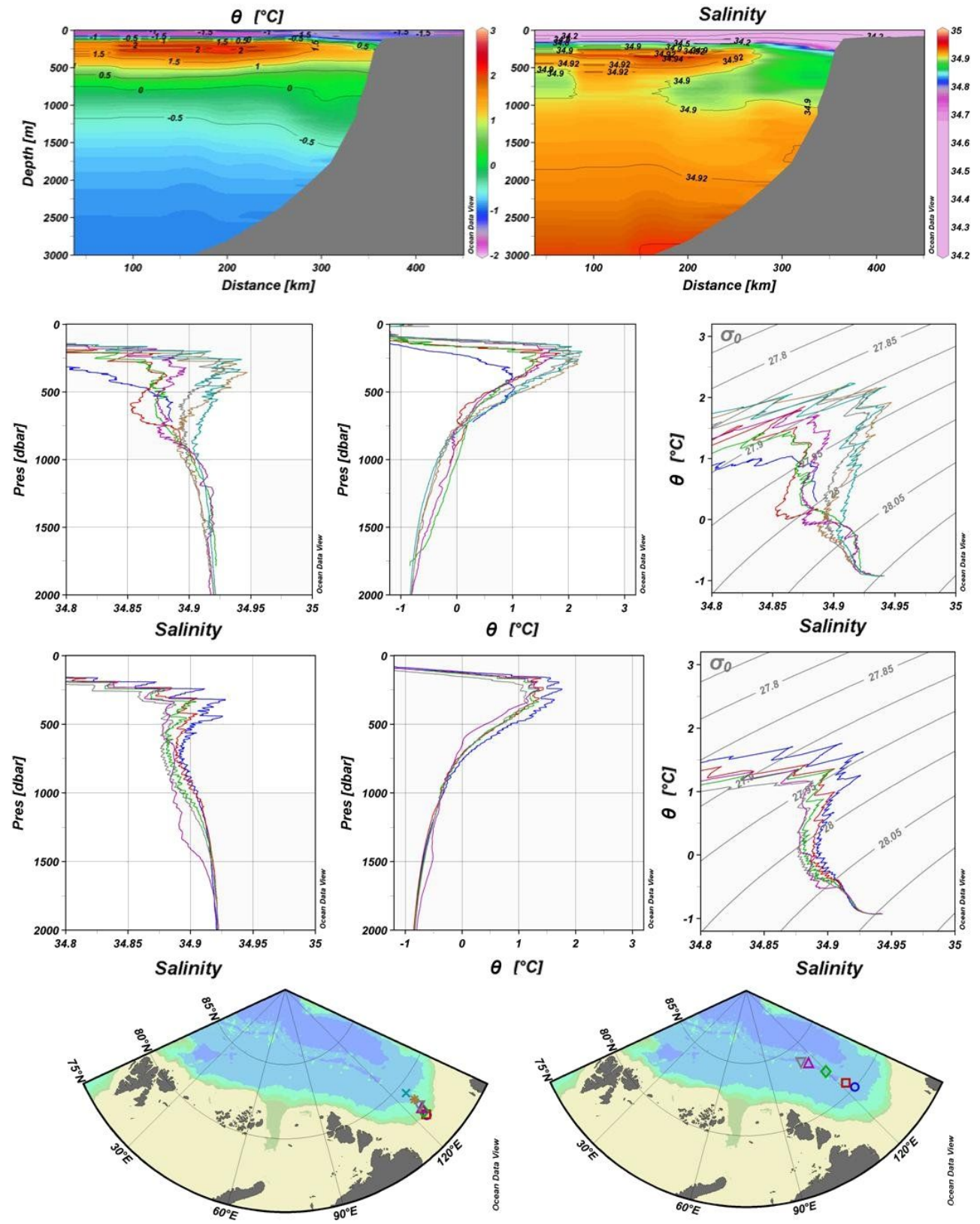

Fig. 13. Water masses mixing and interleaving along the Gakkel Ridge north of the Laptev Sea. Upper panel: temperature and salinity sections from the shelf along the Gakkel Ridge showing a colder and less saline Fram Strait Atlantic core compared to the Kara Sea section (Fig. 12) and the Barents Sea branch water has spread from the slope into the basin. It is also observed on the basin side of the warm core. Upper centre panel: potential temperature and salinity profiles and $\theta S$ curves from the slope showing interleaving between the two branches. Note that no smooth warm and saline Atlantic core is present. Interleaving layers are found everywhere. Lower centre panel: potential temperature and salinity profiles and $\theta S$ curves along the Gakkel Ridge showing the interleaving structures. Lower panel: maps showing the positions of the stations. Data from Polarstern 2007.

\section{The deep and bottom waters}

Differences between the water columns in the basins indicate that water mass transformations are taking place, changing the properties of the water masses as they are advected through the Arctic Mediterranean Sea. Because of the strong stability in the upper part of the Arctic Ocean, any changes occurring in the deeper layers must be caused by processes taking place at the rim. The most obvious mechanism for creating dense water capable of sinking into the deep basins is, as Nansen (1906) already pointed out, freezing and brine rejection over shallow areas, where the brine can accumulate 

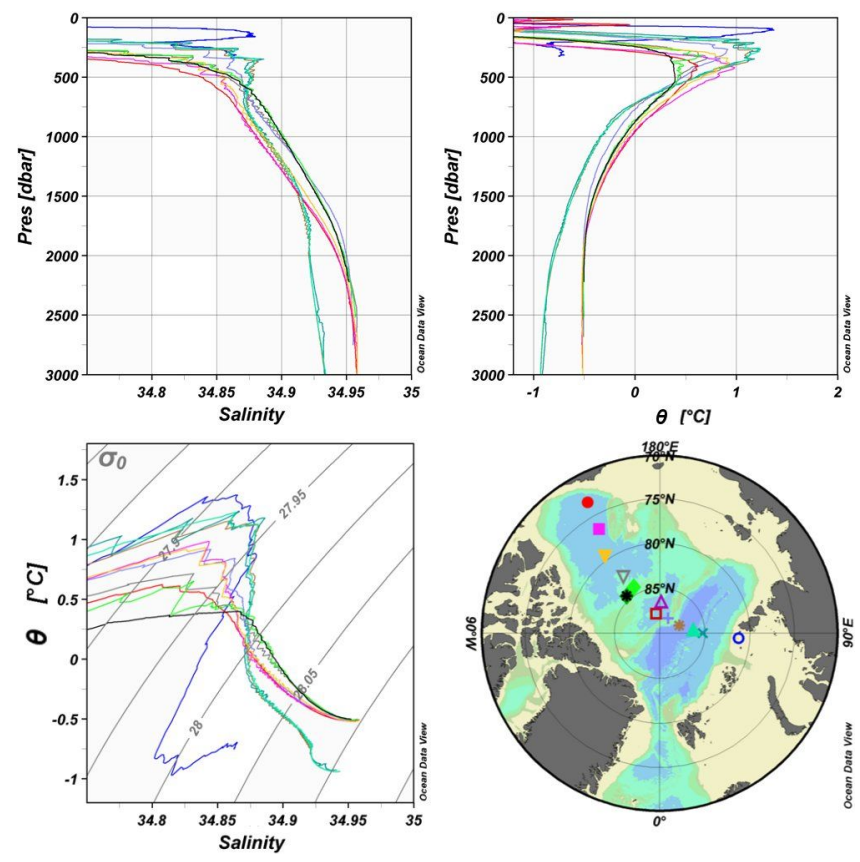

Fig. 14. Potential temperature and salinity profiles and $\theta \mathrm{S}$ curves comparing the Barents Sea branch characteristics with those found in the other basins. The Barents Sea branch could, at least in principle, supply the Atlantic and intermediate water to the Arctic Ocean Basins beyond the Nansen Basin and the Gakkel Ridge. Data from Polarstern 2007 and Oden 2005.

and generate cold, highly dense bottom water. Evidence that such process is active had then already been found e.g. close to the coast of Novaya Zemlya, where a lee polynya forces ice away from the coast, allowing for larger ice production and stronger brine rejection (Knipowisch, 1905) (Fig. 15).

As the cold, saline waters cross the shelf break and sink down the slope into the deep basins they entrain ambient water and become less dense. Depending upon their initial density they sink to different depths, where the final density matches that of the surroundings. There they merge with and change the characteristics of the boundary current. Initially less dense plumes supply the halocline in the Canada Basin (Jones and Anderson, 1986) and cool and freshen the Atlantic layer, while denser plumes sink deeper, entraining Atlantic water and become warmer than the ambient waters and thus increase both the temperature and the salinity of the deeper layers (Rudels, 1986b) (Fig. 16). The characteristics of the Atlantic, intermediate and deep waters in the different basins largely agree with such processes. Compared with the Greenland Sea, the second deep water source in the Arctic Mediterranean Sea, i.e. the Arctic Ocean, supplies warmer and more saline deep and bottom waters (Aagaard et al., 1985; Rudels, 1986b) (Fig. 10).

There are deviations from this picture. In the Canada Basin and in the Amundsen and Nansen basins there is a temperature minimum present above the homogenous, warmer and more saline bottom water, at $1200 \mathrm{~m}$ above the bottom in the Canada Basin and at 500-800 $\mathrm{m}$ above the bottom in the Amundsen and Nansen basins (Fig. 17). The higher temperature in the bottom water has been suggested to be caused by geothermal heating (Timmermanns et al., 2003; Björk and Winsor, 2006), which then eventually would remove the temperature minimum. The temperature minimum in the Canada Basin can be explained by advection of colder, less saline deep water from the Makarov Basin across the sills in the Alpha Ridge and the Mendeleyev Ridge (Fig. 17). For the minima in the Amundsen and Nansen basins such explanation is not possible. The temperature minima lie too deep to be caused by deep water advected from the Greenland Sea through Fram Strait. One possibility could be that occasionally cold, dense water is created in the eastern Barents Sea and enters the Arctic Ocean in the St. Anna Trough. It would then entrain less warm water from the boundary current at the slope and could reach the deeper layers still retaining its cold signature (Rudels et al., 2000). However, at present this must remain a speculation.

The Makarov Basin is different. There the salinity becomes constant with depth but the temperature continues to decrease until the $\sim 600 \mathrm{~m}$ thick, homogenous bottom layer is reached (Fig. 17). This structure can neither be explained by geothermal heating nor by slope convection, which would bring warmer water to the deeper layers. Jones et al. (1995) proposed that colder Amundsen Basin deep water could spill over the deepest part in the central Lomonosov Ridge. It would then sink, aided by the fact that colder water is more compressible - i.e. the thermobaric effect (Gill, 1982) - into the deepest layers of the Makarov Basin and cool these.

In 2005 IB Oden and USCGC Healy located the sill of the passage, an intra-basin, where such exchange could occur. However, it was found that the densest water at the sill (depth $1870 \mathrm{~m}$ ) was from the Makarov Basin (Fig. 18, green station). Makarov Basin water filled the intra-basin between sill depth down to $2200 \mathrm{~m}$, overlying denser Amundsen Basin water (Fig. 18, magenta station), and was observed to enter the Amundsen Basin and continue along the slope of the Lomonosov Ridge toward Greenland (Björk et al., 2007). This might be the most important passage for the Amerasian Basin deep water to the Eurasian Basin and then to the Nordic Seas. This outflow is also likely to supply the salinity maximum observed in the Amundsen Basin at 1700$1800 \mathrm{~m}$ depth, which was postulated to derive from the Amerasian Basin deep water (Anderson et al., 1994; Jones et al., 1995).

In 2001 IB Oden was trying to locate this passage in the Lomonosov Ridge and obtained, without realising it then, two stations very close to the sill (Fig. 18, orange station (only one station shown)). These stations, by contrast, showed that the densest water at the bottom (about $1700 \mathrm{~m}$ ) was Amundsen Basin deep water, not Makarov Basin deep water, and if this water continued into the Makarov Basin its density referred to $2000 \mathrm{db}, \sigma_{2}$, corresponded to the density 


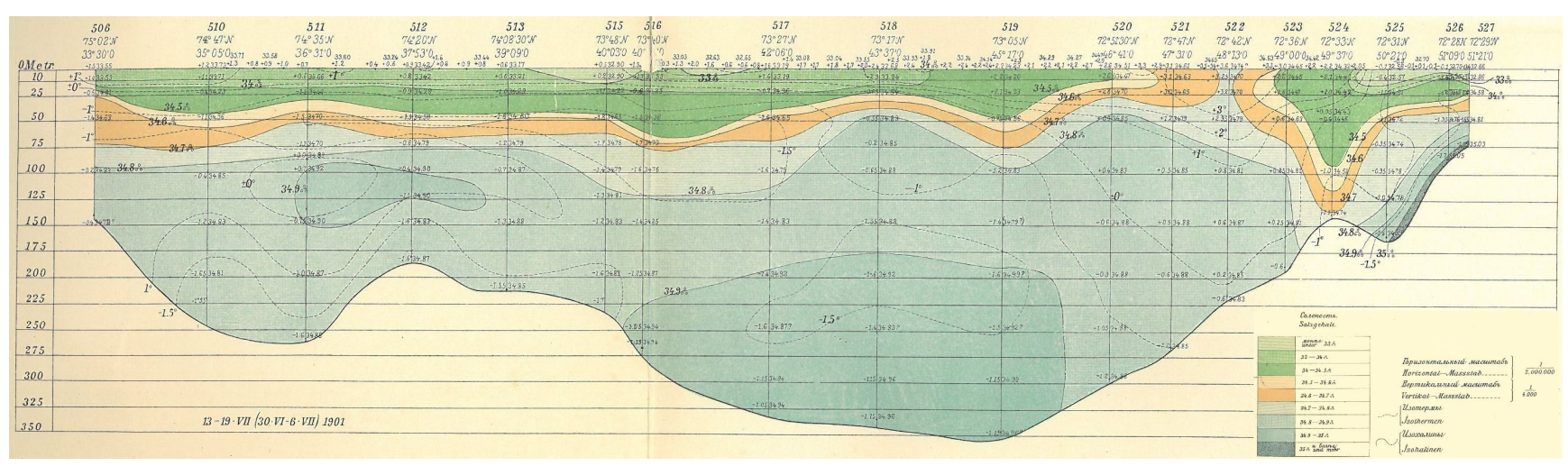

Fig. 15. Temperature and salinity section from $75^{\circ} 02^{\prime} \mathrm{N}, 33^{\circ} 30^{\prime} \mathrm{E}$ (Central Bank) to $72^{\circ} 29^{\prime} \mathrm{N}, 51^{\circ} 21^{\prime} \mathrm{E}$ (Novaya Zemlya) showing cold and brine enriched saline water on the shallow area west of Novaya Zemlya in 1901. From Knipowisch (1905).

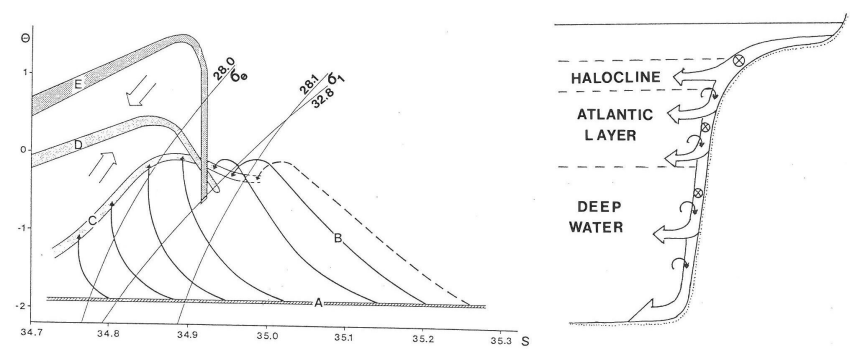

Fig. 16. Schematics showing to the left the evolution of the characteristics of dense shelf waters (A) due to entrainment as they sink down the continental slope (B). Depending upon the initial salinity the final characteristics form an envelope $(\mathbf{C})$, which merges with the boundary current (E) to form the transformed water column (D). An idealised picture of plumes sinking to different depth is shown to the right. From Rudels and Quadfasel (1991).

found at $2500 \mathrm{~m}$ and its density referred to $4000 \mathrm{db}, \sigma_{4}$, was higher than that found at the bottom in the Makarov Basin. This water could then potentially renew and cool the Makarov Basin deep water (Fig. 18).

One possible mechanism for driving such intermittent transports is the pressure gradient at sill depth. Observations in the Beaufort Sea of hydrography, of bottom pressure from pressure gauges mounted at the sea floor, and of gravity and sea level heights obtained from satellites indicate that when a water column becomes less dense the bottom pressure goes down (Kwok et al., 2009). The rise in sea level does not fully compensate the lighter water column, leading to a reduction in bottom pressure. Translating this to the Lomonosov Ridge, a larger dynamical depth implies a less dense water column. In 2005 the dynamic height between the sea surface and 2000db was larger in the Amundsen Basin than in the Makarov Basin, indicating that the negative pressure gradient along a geopotential surface at about $2000 \mathrm{~m}$ would be directed from the Makarov Basin to the Amundsen Basin. This would force water at sill depth from the Makarov Basin into the intra-basin and then to the Amundsen Basin. No similar
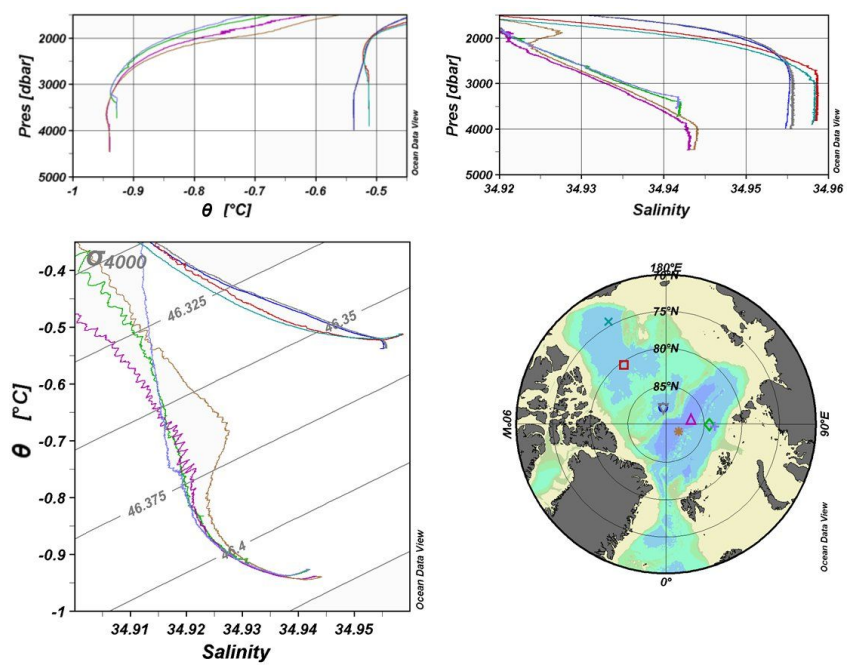

Fig. 17. Deep and bottom water characteristics from the Nansen Basin, Amundsen Basin, Makarov Basin and Canada Basin. Note the absence of a deep temperature minimum in the Makarov Basin and that the temperature minimum observed in the Canada Basin could derive from the Makarov Basin and the deep salinity maximum in the Amundsen Basin could be caused by Makarov Basin deep water crossing the Lomonosov Ridge.

section exists from 2001, but a section across the Lomonosov Ridge taken by Polarstern in 1996 shows that the dynamic height between the sea surface and 2000db then was smaller in the Amundsen Basin than in the Makarov Basin and the direction of the pressure gradient would be reversed, favouring a flow at the sill from the Amundsen to the Makarov Basin (Fig. 19). It is thus conceivable that the deepest exchange across the sill varies in time and intermittently denser Amundsen Basin water is brought into the Makarov Basin and sinks into the deep, cooling the bottom water. The other mixing end member would be deep water from the Canada Basin, which, in the absence of a spill over, would gradually increase the salinity and temperature of the Makarov Basin 

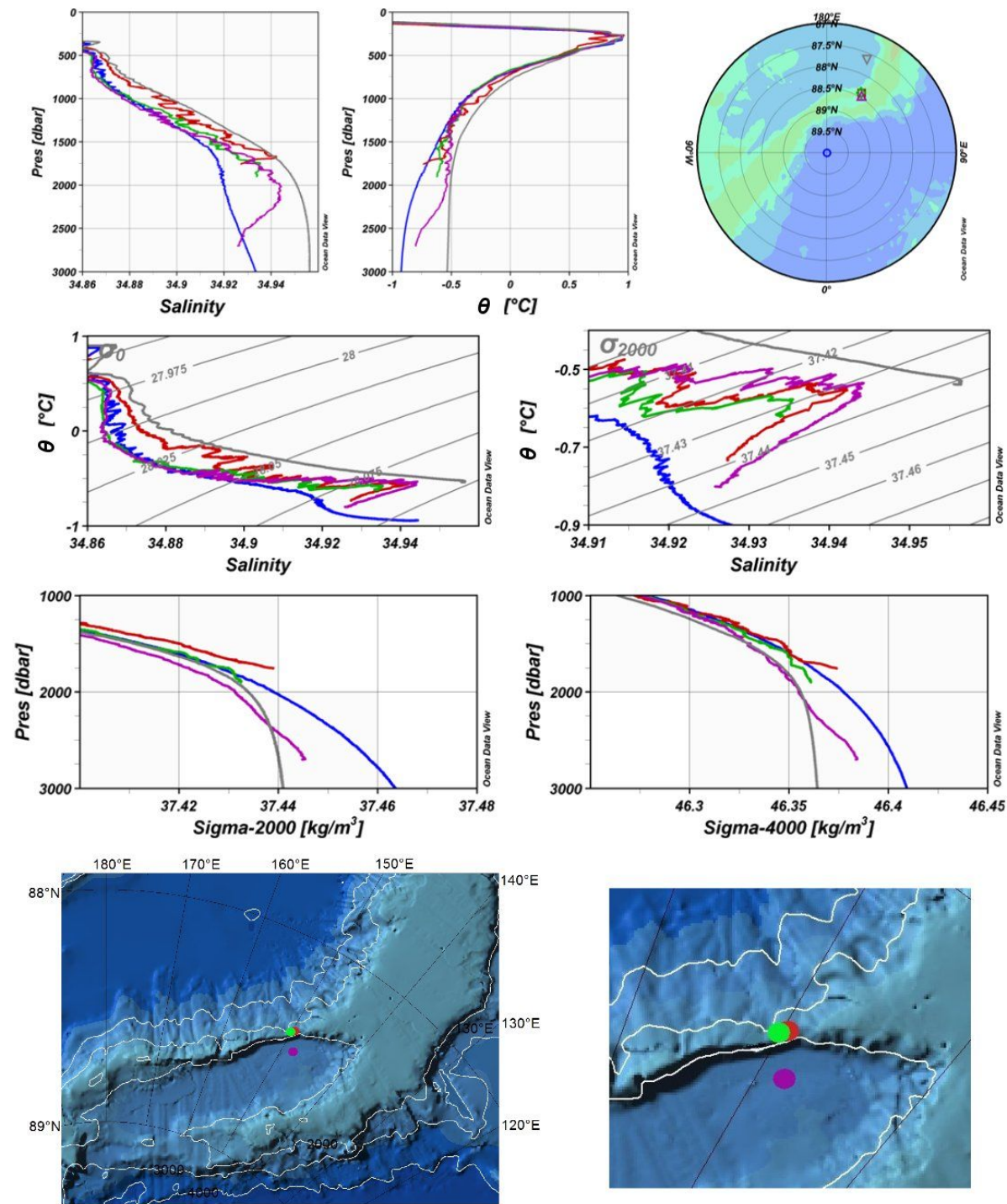

Fig. 18. Potential temperature and salinity profiles and $\theta S$ curves from stations in the Makarov Basin, the Amundsen Basin and the intrabasin in the Lomonosov Ridge (lower map left). The magenta station from the interior of the intra-basin and the green station at the sill (lower map right), as well as the stations in the Amundsen and Makarov basins, were taken in 2005 by Oden. The orange station at the sill was taken by Oden in 2001. The 2001 station indicates that water deriving from the Amundsen Basin deep water was present in the deepest part, located above the sill depth to the Makarov Basin. If this water crossed the sill, it could sink down to $2500 \mathrm{~m}$ in the Makarov Basin.

bottom water. Such temperature and salinity increases have been reported (see e.g. Timmermanns and Garrett, 2006) but especially the salinity increase is close to the observational uncertainty.

\section{The exchanges through Fram Strait}

Fram Strait is the deepest $(2600 \mathrm{~m})$ and the most important connection between the Arctic Ocean and, via the Nordic Seas, the world ocean. It has a two-directional exchange. To the east, warm Atlantic water and also Arctic intermediate and deep waters from the Nordic Seas are carried northward in the West Spitsbergen Current, while in the west the East Greenland Current transports low salinity Polar surface water, cooled and transformed Arctic Atlantic Water and different Arctic Ocean intermediate and deep waters southward to the Nordic Sea (Fig. 20). The net transport is about $2 \mathrm{~Sv}$ out of the Arctic Ocean and the mean total in- and outflows are estimated to $7 \mathrm{~Sv}$ and $9 \mathrm{~Sv}$, respectively, based on geostrophy (Rudels et al., 2008) and to $12 \mathrm{~Sv}$ and $14 \mathrm{~Sv}$ from direct current observations (Schauer et al., 2008). The flow has a strong barotropic component, strongest in the West Spitsbergen Current but significant also in the East Greenland Current, which makes geostrophic calculations unreliable 

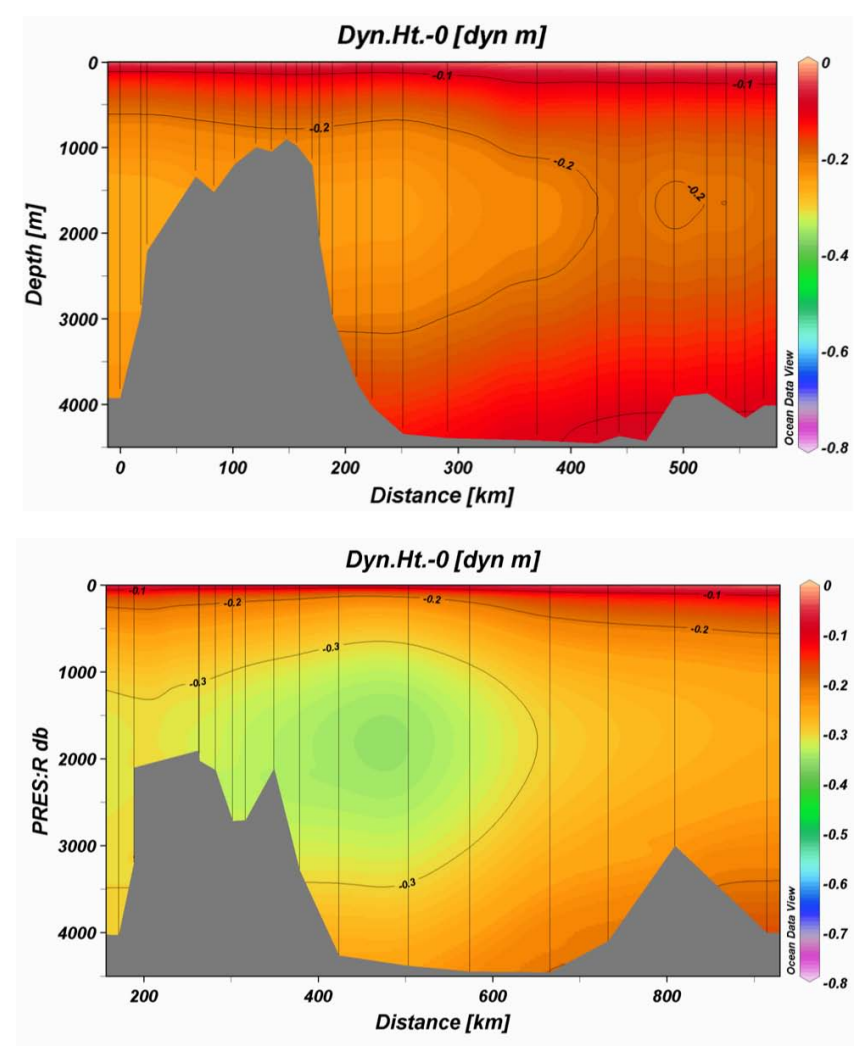

Fig. 19. Sections of dynamical heights across the Lomonosov Ridge with the Makarov Basin to the right and the Amundsen Basin to the left taken from Polarstern 1996 (upper panel) and Oden 2005 (lower panel). In 2005 the dynamic height between 0 and 2000db was larger in the Amundsen Basin then in the Makarov Basin indicating a negative pressure gradient at sill depth directed from the Makarov Basin into the Amundsen Basin that could block the inflow of Amundsen Basin deep water into the Makarov Basin. In 1996 this situation was reversed.

and subjective, depending upon how the unknown barotropic component is handled or approximated. Direct current measurements have been carried out in Fram Strait since 1997 by the Alfred Wegener Institute and the Norwegian Polar Institute with a mooring array consisting presently of 16 individual moorings (see Sect. 2 above). Here difficulties also arise due to the presence of baroclinic and barotropic eddies with small horizontal scales, which complicate the transport estimates.

Perhaps a more fundamental question to ask is - How are the exchanges through Fram Strait driven? - Are they mainly forced by the atmospheric circulation or are the thermodynamic processes taking place in the Arctic Ocean and in the Nordic Seas of equal, or greater, importance?

Nøst and Isachsen (2003) noticed that the Arctic Mediterranean offered closed geostrophic contours, which would allow for a barotropic circulation conserving potential vorticity. They estimated the flow along geostrophic contours by requiring a balance between the vorticity input by the wind in the area enclosed by the streamline and the dissipation of vorticity by bottom friction along the streamline, obtaining a realistic circulation pattern. No buoyancy forcing was applied in the original formulation but in a more recent attempt (Aaboe and Nøst, 2008) the effects of observed changes in bottom density along the circulation path was considered and indicated that a reduction of the bottom density would change the barotropic current into a more baroclinic flow.

The laboratory experiments performed by Hunkins and Whitehead (1992), using a tank divided by a wall with an opening, a "strait", and forcing one side with cyclonic, the other with anticyclonic winds, showed that the initially evenly distributed upper layer water were forced into the anticyclonic, Arctic Ocean, part of the tank. The interpretation made by Hunkins and Whitehead was that the outflow of low salinity surface water through the strait into the "Nordic Seas" had to be driven by buoyancy and had to occur as a buoyant boundary current. This, however, does not explain much about the Atlantic and intermediate water inflow to the Arctic Ocean.

To highlight an extreme case, we here pose the question: is it possible to have a geostrophically balanced exchange through Fram Strait so strong that the thermohaline transformations occurring in the Arctic Ocean are just sufficient to create the density field in Fram Strait required for fulfilling the transports needed for the transformations?

To examine this situation we construct two water columns, one representing the West Spitsbergen Current the other the East Greenland Current. The geostrophic flow is driven by the density differences between the two water columns and the sea level slope. Following Rudels (1989) we further assume that there is no flow against the negative pressure gradient. In the classical two station geostrophic calculation the transport between the stations would vary in the vertical and water with averaged $\theta S$ characteristics would be transported north or south. When we only look at a two-layer system with a buoyant current at the wall, it is usual to consider the deeper layer as motionless (station A) and reaching the surface, still motionless, at, or before, station B. Only water with upper layer characteristics is then transported. In the present situation with two boundary currents and several layers we try to extend the simple boundary layer approach to also involve the water masses located in the deeper part of the water columns and at the same time avoid transporting water masses with unrealistic characteristics. The flow will change direction as the pressure gradient changes sign with depth but only one water mass, represented by one or the other station, will move between two pressure gradient reversals.

This means that there will be a southward flow in the upper part of the East Greenland Current, while there is no northward transport in the West Spitsbergen Current at the same level. First below the pressure gradient reversal, where the negative pressure gradient is directed into the Arctic Ocean, or from the West Spitsbergen Current to the East Greenland Current, does the Atlantic water flow northward into the 

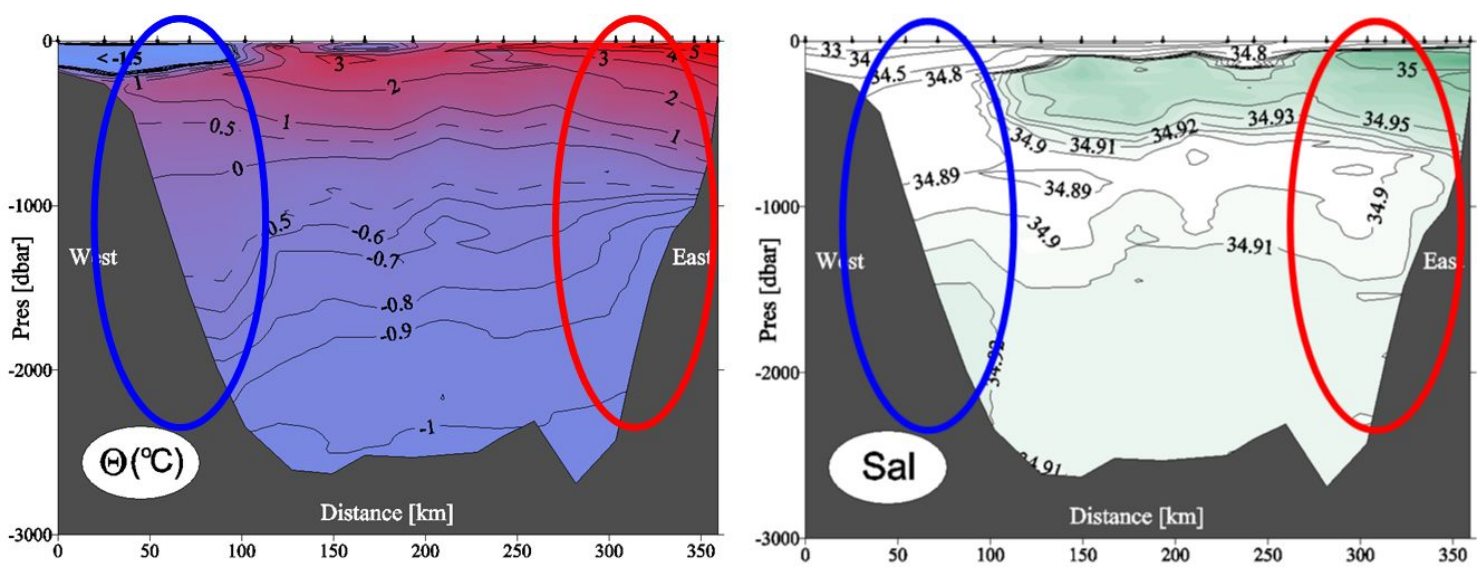

Fig. 20. Potential temperature and salinity sections from Fram Strait taken in 1997 by RV Lance. The West Spitsbergen Current and the East Greenland Current are indicated by red and blue ellipses respectively.

Arctic Ocean. At this level the outflow in the East Greenland Current is blocked.

We only consider Fram Strait. The inflow through Bering Strait is taken to exit through the Canadian Arctic Archipelago and the inflow over the Barents Sea is presently ignored. The river runoff is assumed first to be frozen to sea ice and then a part of the sea ice is melted by heat supplied by the inflowing Atlantic water. Taking the Atlantic water temperature to be $3.1^{\circ} \mathrm{C}$ and the salinity 35 and the density $\rho$ is approximated by:

$\rho=\rho_{\mathrm{f}}(1-\alpha(T-0.6)+\beta S)$

Here $0.6{ }^{\circ} \mathrm{C}$ is the mean temperature of the Atlantic water set to $3.1^{\circ} \mathrm{C}$ and the outflow at freezing temperature, $-1.9^{\circ} \mathrm{C}$, $\alpha=0.6 \times 10^{-4}$, and $\beta=8 \times 10^{-4}$ (Gill, 1982). From the expression for the salinity of the upper layer (Eq. 17), the upper layer salinity, $S_{1}$, becomes 34.27 . A possible salinity increase due to brine rejection is ignored.

The river runoff to the Arctic Ocean, and thus the ice export, is about $0.1 \mathrm{~Sv}$ and we first assume that $0.02 \mathrm{~Sv}$ is melted by heat carried by the Atlantic water. The amount of low salinity Polar water leaving the Arctic Ocean can then be computed from the Knudsen relations (Knudsen, 1900):

$M_{1}=M_{\mathrm{A}}+0.02$,

$S_{1} M_{1}=S_{\mathrm{A}} M_{\mathrm{A}}$

The thickness of the moving part of the upper layer is then found from Werenskiold's formula (Eq. 1) with $\mathrm{H}_{1}$ being the depth of the pressure reversal given by:

$\rho_{1} H_{1}=\rho_{\mathrm{A}}\left(H_{1}-\delta\right)$

where $\delta$ is the sea level difference between the two water columns. The inflow of Atlantic water takes place below $H_{1}$ and to transport the needed volume $M_{\mathrm{A}}$ a thickness $H_{\mathrm{A}}$ is required, which can be determined from the geostrophic transport;

$M_{\mathrm{A}}=\frac{g}{\rho f}\left\{\left(\rho_{\mathrm{A}}-\rho_{1}\right) \frac{H_{\mathrm{A}}}{2}\right\} H_{\mathrm{A}}$

However, the pressure gradient driving the Atlantic water cannot be removed with depth even if the depth of the upper layer in the East Greenland Current would be less than $\mathrm{H}_{1}+$ $\mathrm{H}_{\mathrm{A}}$, and the Atlantic water will continue to flow into the Arctic Ocean in the deep (Fig. 21). This leads to an imbalance of the exchanges and the sea surface in the Arctic Ocean would start to rise. A barotropic outflow is then generated, which balances the inflow. The exchanges become larger than those necessary to create the required density field.

So far the fact that also denser waters are produced in the Arctic Ocean has not been taken into account. To simplistically do so, we allow some of the low salinity Polar water to flow onto the shelves, where its salinity is increased by brine rejection to 35 , while its temperature remains at the freezing point, $-1.9^{\circ} \mathrm{C}$. In the three examples considered, $25 \%, 50 \%$ and $75 \%$ of the Polar surface water is assumed to flow onto the shelves (Tables 1 and 2). As the shelf water descends down the slope, it entrains ambient water and we consider five cases, where the entrainment increases the volume of the convecting shelf water by $0 \%, 20 \%, 40 \%, 60 \%$ and $80 \%$ (Tables 1 and 2). The salinity 35 for layer 3 is chosen to simplify the computations of the density of the outflowing deep water, which then has the same salinity as the Atlantic water and only differs in temperature. The density of the deep water should be considered as an average of the denser waters formed in the Arctic Ocean, the Arctic Atlantic water and the intermediate and the deep waters.

To export the deep water from the Arctic Ocean, a second pressure reversal must exist, where the negative pressure gradient is directed out of the Arctic Ocean. The second 
Table 1. Properties of the Atlantic water, the Polar surface water and the deep water for different percentages of entrained ambient (Atlantic) water.

\begin{tabular}{lrrr|rrr|rrr}
\hline Entrained water $\%$ & \multicolumn{3}{c|}{ Polar surface water } & \multicolumn{2}{c|}{ Atlantic water } & \multicolumn{2}{c}{ Outflowing deep water } \\
\cline { 2 - 9 } & $\begin{array}{r}\text { Temp } \\
\left({ }^{\circ} \mathrm{C}\right)\end{array}$ & Sal & $\begin{array}{r}\text { Density } \\
\left(\mathrm{kg} \mathrm{m}^{-3}\right)\end{array}$ & $\begin{array}{r}\text { Temp } \\
\left({ }^{\circ} \mathrm{C}\right)\end{array}$ & Sal & $\begin{array}{r}\text { Density } \\
\left(\mathrm{kg} \mathrm{m}^{-3}\right)\end{array}$ & $\begin{array}{r}\text { Temp } \\
\left({ }^{\circ} \mathrm{C}\right)\end{array}$ & $\begin{array}{r}\text { Sal } \\
\left(\mathrm{kg} \mathrm{m}^{-3}\right)\end{array}$ \\
\hline 0 & -1.9 & 34.27 & 27.56 & 3.1 & 35 & 27.85 & -1.9 & 35 & 28.15 \\
20 & -1.9 & 34.27 & 27.56 & 3.1 & 35 & 27.85 & -0.9 & 35 & 28.09 \\
40 & -1.9 & 34.27 & 27.56 & 3.1 & 35 & 27.85 & 0.1 & 35 & 28.03 \\
60 & -1.9 & 34.27 & 27.56 & 3.1 & 35 & 27.85 & 1.1 & 35 & 27.97 \\
80 & -1.9 & 34.27 & 27.56 & 3.1 & 35 & 27.85 & 2.1 & 35 & 27.91 \\
\hline
\end{tabular}

Table 2. Transports of Atlantic water, Polar surface water and deep water for different amount of Polar surface water transformed on the shelves and different percentages of entrained ambient (Atlantic) water.

\begin{tabular}{|c|c|c|c|c|c|c|c|c|c|c|c|c|}
\hline \multirow{3}{*}{$\begin{array}{l}\text { Ent } \\
\%\end{array}$} & \multicolumn{4}{|c|}{ Polar surface water transport } & \multicolumn{4}{|c|}{ Atlantic water transport } & \multicolumn{4}{|c|}{ Deep water outflow } \\
\hline & \multicolumn{4}{|c|}{ Water to shelves $(\mathrm{Sv})$} & \multicolumn{4}{|c|}{ Water to shelves $(\mathrm{Sv})$} & \multicolumn{4}{|c|}{ Water to shelves (Sv) } \\
\hline & 0 & 0.24 & 0.48 & 0.72 & 0 & 0.24 & 0.48 & 0.72 & 0 & 0.24 & 0.48 & 0.72 \\
\hline 0 & 0.96 & 0.72 & 0.48 & 0.24 & 0.94 & 0.94 & 0.94 & 0.94 & 0 & 0.24 & 0.48 & 0.72 \\
\hline 20 & 0.96 & 0.72 & 0.48 & 0.24 & 0.94 & 1.03 & 1.06 & 1.1 & 0 & 0.30 & 0.60 & 0.90 \\
\hline 40 & 0.96 & 0.72 & 0.48 & 0.24 & 0.94 & 1.10 & 1.26 & 1.44 & 0 & 0.40 & 0.80 & 1.20 \\
\hline 60 & 0.96 & 0.72 & 0.48 & 0.24 & 0.94 & 1.30 & 1.66 & 2.04 & 0 & 0.60 & 1.20 & 1.80 \\
\hline 80 & 0.96 & 0.72 & 0.48 & 0.24 & 0.94 & 1.90 & 2.86 & 3.84 & 0 & 1.20 & 2.40 & 3.60 \\
\hline
\end{tabular}

pressure reversal is given by;

$$
\begin{aligned}
& g \rho_{\mathrm{A}}\left(H^{\prime}+H^{\prime \prime}\right)=g \rho_{1} H^{\prime}+g \rho_{3} H^{\prime \prime} \text { or } g\left(\rho_{\mathrm{A}}-\rho_{1}\right) H^{\prime} \\
& \quad=-g\left(\rho_{\mathrm{A}}-\rho_{3}\right) H^{\prime \prime}
\end{aligned}
$$

where $H^{\prime}$ is the thickness of the Atlantic inflow layer that lies beside the upper Polar water and the pressure gradient increases with depth, and $H^{\prime \prime}$ is the thickness of the part of the Atlantic layer that lies beside the deep water and the pressure gradient decreases with depth (Fig. 22). The transport $M_{\mathrm{A}}$ in the Atlantic layer than becomes (Rudels, 1989);

$$
\begin{aligned}
M_{\mathrm{A}} & =\frac{g}{\rho f}\left\{\left[\left(\rho_{\mathrm{A}}-\rho_{1}\right) \frac{H^{\prime}}{2}\right] H^{\prime}\right. \\
& \left.+\left[\left(\rho_{\mathrm{A}}-\rho_{1}\right) H^{\prime}+\left(\rho_{\mathrm{A}}-\rho_{3}\right) \frac{H^{\prime \prime}}{2}\right] H^{\prime \prime}\right\}
\end{aligned}
$$

Since $M_{\mathrm{A}}$ is known from the transformations, $H^{\prime}$ and $H^{\prime \prime}$, can be determined from Eqs. (23) and (24) leading to;

$$
\begin{aligned}
& H^{\prime \prime}=\left\{\frac{2 M_{\mathrm{A}} \rho f}{g} \frac{\left(\rho_{1}-\rho_{3}\right)\left(\rho_{\mathrm{A}}-\rho_{3}\right)}{\left(\rho_{\mathrm{A}}-\rho_{1}\right)}\right\}^{1 / 2} \text { and } \\
& H^{\prime}=-\frac{\left(\rho_{\mathrm{A}}-\rho_{3}\right)}{\left(\rho_{\mathrm{A}}-\rho_{1}\right)} H^{\prime \prime}
\end{aligned}
$$

The minimum thickness of the outflow of deep water $\mathrm{H}_{3}$, required to have mass balance, is finally found by solving;

$M_{3}=\frac{g}{\rho f}\left\{\left(\rho_{3}-\rho_{\mathrm{A}}\right) \frac{H_{3}}{2}\right\} H_{3}$

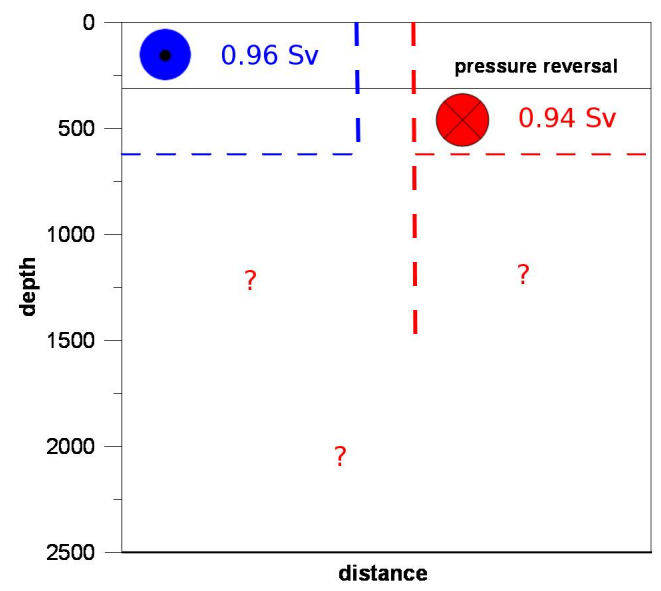

Fig. 21. Idealised baroclinic exchanges through Fram Strait, where the upper layer in the East Greenland Current is created by allowing $0.02 \mathrm{~Sv}$ of ice to melt on the Atlantic water. The salinity of the low salinity layer, 34.27 , is determined from the constraint that minimum heat goes to ice melt. The Atlantic water has temperature $3.1^{\circ} \mathrm{C}$ and salinity 35 . The southward flow only takes place above and northward flow only below the pressure gradient reversal. The horizontal dashed red line indicates at what depth the northward flowing Atlantic water balances the southward flowing Polar water. Only one pressure reversal in created and nothing, except the rise in sea level, will stop the northward flow of Atlantic water. This would add a barotropic component to the southward flow. 

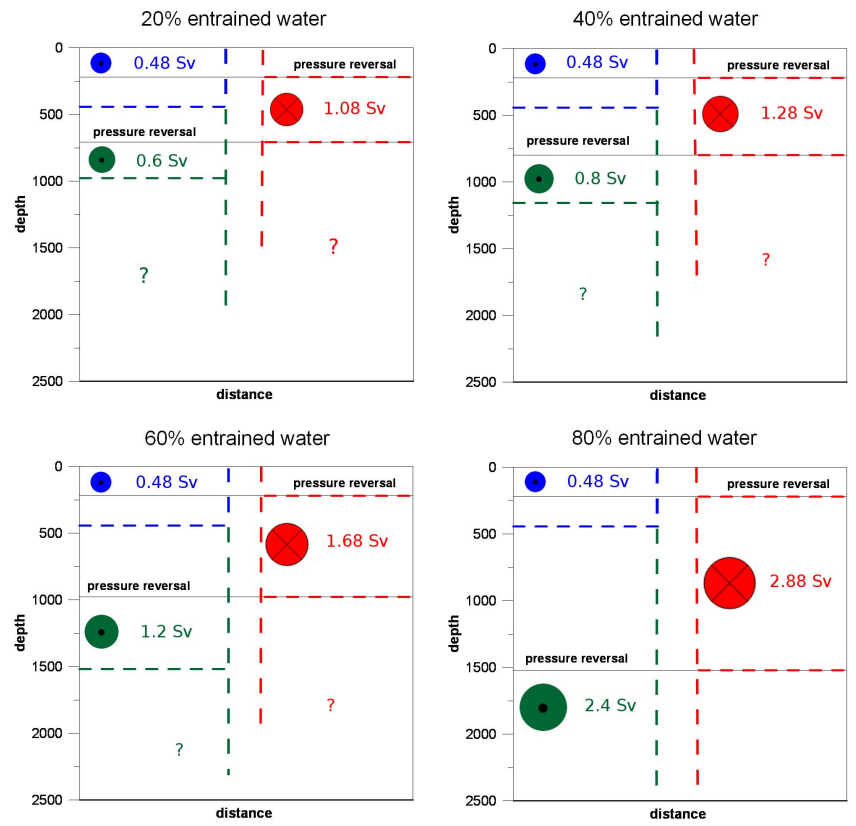

Fig. 22. Idealised baroclinic exchanges through Fram Strait. Half of the Polar water in the low salinity upper layer is assumed to be transformed by ice formation and brine rejection on the shelves, increasing the salinity to 35 , and the shelf water sinks down the slope entraining ambient (Atlantic) water. The increased density in the lower layer creates a second pressure reversal and a deep southward flow is generated. However, the deep flow does not cease, when mass balance is reached and the sea level in the Arctic Ocean will drop, adding a barotropic component to the northward Atlantic flow to conserve mass. The southward flow of Polar water is above the first pressure gradient reversal, but Polar water is found down to the horizontal dashed blue line. The northward flow of Atlantic water occurs between the pressure gradient reversals but the entire eastern water column consists of Atlantic water. The deep Arctic Ocean water is located below the dashed blue line but the southward flow only takes place below the second pressure reversal. The horizontal dashed green line indicates the depth, where mass balance is achieved.

for $H_{3}$, where $\mathrm{H}_{3}$ is located below the second pressure reversal (Fig. 22). However, again similar difficulties arise. The pressure gradient will continue to increase and the deep southward flow will be present below the depth, where mass balance is achieved $\left(H_{1}+H^{\prime}+H^{\prime \prime}+H_{3}\right)$ (Fig. 22). The sea level in the Arctic Ocean will decrease and generate a compensating barotropic inflow to maintain mass balance.

It thus appears that it is not possible to create a baroclinic exchange that exactly balances the changes in water mass properties. The water mass transformations generate a barotropic flow component through the strait. This would then add to any wind driven barotropic transport created by the atmospheric circulation.

These simple considerations nevertheless allow for the construction of temperature and salinity fields as well as the current field in Fram Strait for different estimates of Atlantic water sensible heat going to ice melt and of the amount of dense water produced on the shelves with different entrainment rates for the slope convection. By comparing the constructed velocity and property fields with those observed, some ideas about what scenarios best correspond to reality might be found. The case with $50 \%$ of the created Polar water being transferred to the shelf areas and then transformed into deep water with an entrainment increase of $60 \%$ seems to resemble the observed density field and baroclinic velocity structure and transports reasonably well (Fig. 22). An example with $75 \%$ transferred to the shelves with $60 \%$ of entrained water is shown in Fig. 23. The heat loss of the Atlantic water is mainly to ice melt and to the atmosphere. Because of the entrainment, most of the inflowing Atlantic water returns as colder intermediate and deep water but this exchange does not provide any Atlantic heat to the Arctic. It remains in the water column. The heat lost to the atmosphere on the shelves is provided by the ice formation and the subsequent ice export. With the chosen value for ice melt $0.02 \mathrm{~Sv}$, the sensible heat supplied to the Arctic by the $0.94 \mathrm{~Sv}$ cooled Atlantic water is about $19 \mathrm{TW}$ of which about $7 \mathrm{TW}$ go to ice melt and the rest, $12 \mathrm{TW}$, is given up to the atmosphere. This should be compared with the ice export, which, with $0.09 \mathrm{~Sv}$, corresponds to about $30 \mathrm{TW}$ going to the atmosphere.

The dense water formation in the Greenland Sea has been neglected, which, when advected to Fram Strait, might balance the pressure gradient in the deep layers. We have also not considered the inflow over the Barents Sea that provides additional low salinity Polar surface water as well as intermediate waters that also exit through Fram Strait. In fact, much of the shelf water that becomes transformed into denser water is supplied by the Barents Sea inflow branch and also partly by the Bering Sea inflow over the Chukchi shelf. Those additional transports could, and should, be added to create a more realistic flow field and density structure in Fram Strait.

This approach is nevertheless highly artificial. To be of any practical use it should be related to some observable parameters. The sea level difference, $\delta$, could be one such parameter, which would give an independent estimate of $H_{1}$. To obtain estimates of the part of the Atlantic inflow that contributes to the intermediate and deep water production is more difficult and would require at least that values for the mean salinity and temperature of the intermediate and deep water outflow can be assessed, assuming that these remain fairly constant because of the large residence time in the Arctic Ocean $(>20 \mathrm{yr})$.

The exchanges are thus larger than the driving buoyancy forcing alone would require even in this simple baroclinic approach. The water that is transported into and out of the Arctic Ocean could then, in principle, supply more heat to the Arctic, which is not detected by the baroclinic field. This also holds for a barotropic current following the bottom topography and forced by the atmospheric circulation. Furthermore, the barotropic and baroclinic eddies present in the central part of Fram Strait are also not considered (Fig. 23). 

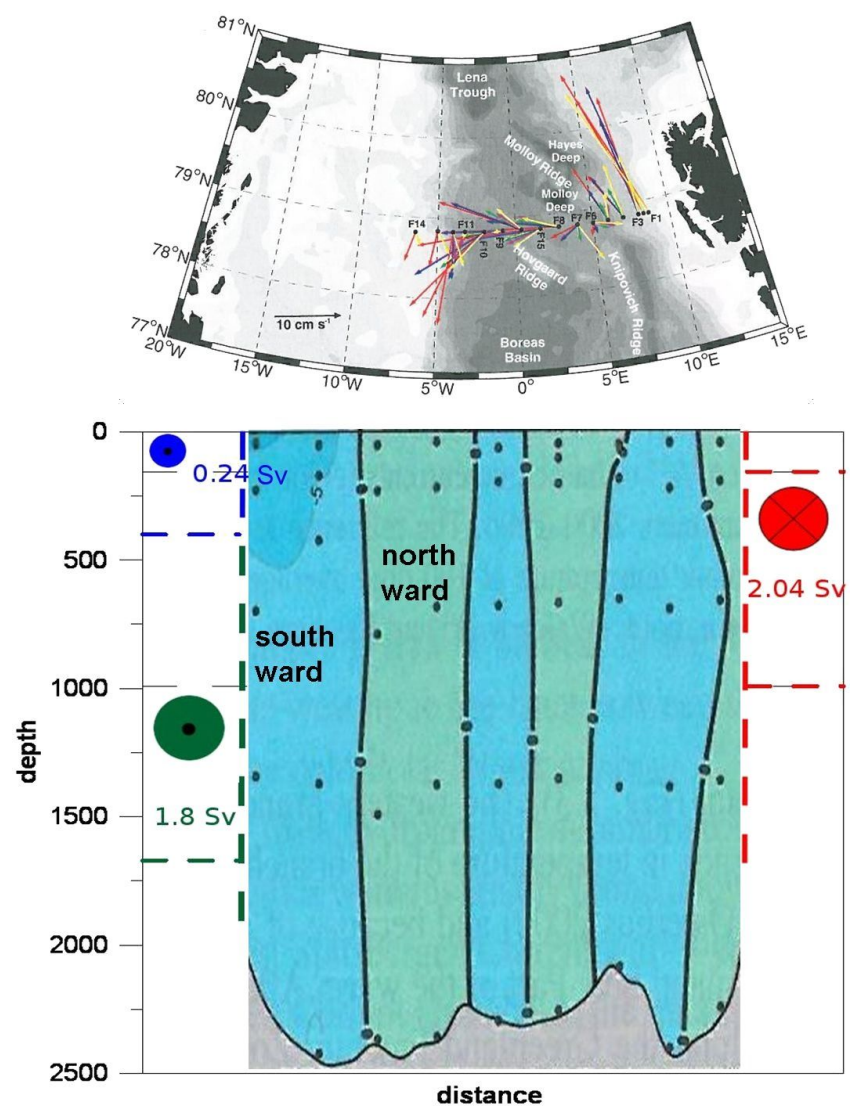

Fig. 23. The idealised transports in the boundary current shown together with the observed barotropic eddies and the recirculation occurring in the central part of Fram Strait (from Schauer et al., 2008). Here the situation with $75 \%$ of the upper layer water transformed on the shelves to dense shelf water and an entrainment of $60 \%$ is shown. Does such idealised two-ways picture contribute to our understanding in view of the energetic exchanges occurring in the central part of Fram Strait?

This is largest part of the strait, and eddies have been shown to interact and create transports in the West Spitsbergen Current and in the East Greenland Current amounting to several Sv (Nazarenko et al., 1998).

The primary assumption made here is that all these large barotropic exchanges do not add significantly to the effective heat and freshwater transports carried by the baroclinic boundary currents. This in turn implies that larger transports essentially only lead to smaller changes and transformations of the water masses, and that the heat and freshwater transports are constrained by the forcing and stratification in the Arctic Ocean. To determine if this is the case is the perhaps most important question that should, and perhaps also can, be answered in the near future.
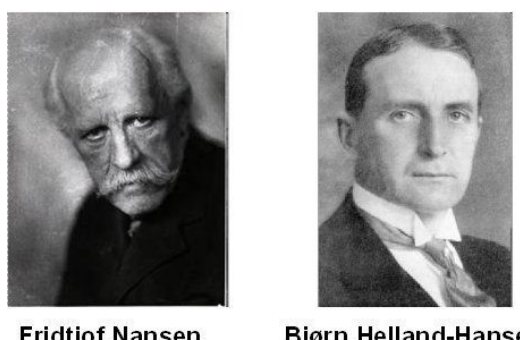

Bjørn Helland-Hansen
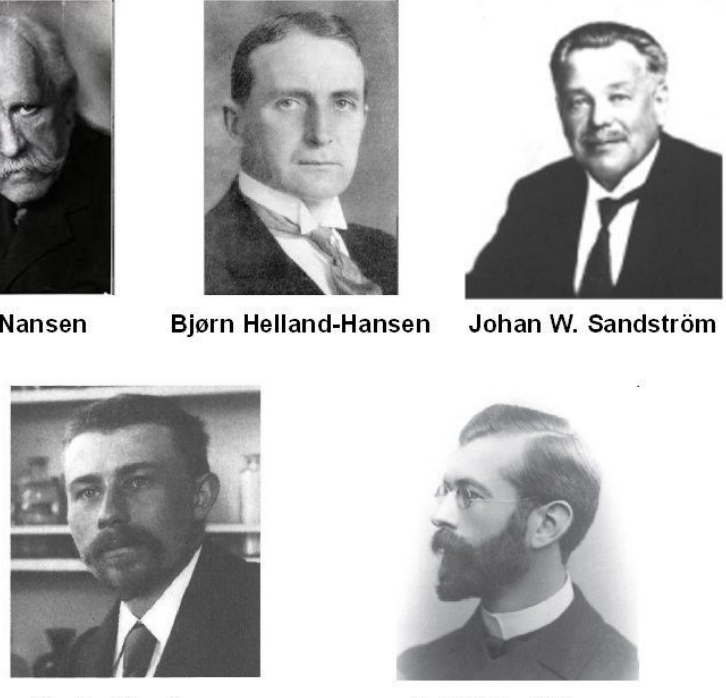

Martin Knudsen

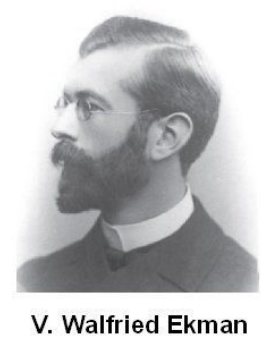

Fig. 24. Pictures of: Fridtjof Nansen, Bjørn Helland-Hansen, Johan W. Sandström, Martin Knudsen, and V. Walfrid Ekman. All images, except that of Martin Knudsen, have been obtained from Wikipedia. The picture of Martin Knudsen has been supplied by Dr Niels Højerslev.

\section{Summary}

This overview has presented some instances in the history of the exploration and study of the Arctic Ocean, and some basic themes in Arctic Ocean oceanography have been examined, following ideas and using methods introduced by oceanographers in the early 20th century (Fig. 24): The vision, exploration and insights of Nansen $(1902,1906)$, Knudsen's relations (1900), the dynamic method introduced in oceanography by Sandström and Helland-Hansen (1903) and $\theta S$ analysis first employed by Helland-Hansen (1916). Concepts and ideas that focus on and are essential for, understanding the water mass transformations and transports taking place in the Arctic Ocean. One concept has largely been neglected, the wind driven ocean circulation. This is perhaps the most important part for describing the circulation, if not the water mass transformations, in the Arctic Ocean and was also first formulated by Ekman (1905) based on observations from Nansen's voyage with Fram.

Acknowledgements. I want to thank Meri Korhonen at the Finnish Meteorological Institute for her help with the figures, and Göran Björk at the University of Gothenburg for supplying the Oden 2001 data. Financial support for this work has been given by he EU project THOR (ThermoHaline Overturning - at Risk?) contract number 212643. Rainer Schlitzer's Ocean Data View (Schlitzer, 2012) has been used to make many of the figures. The historical information given in Sect. 1 has mainly been taken from Laktionov (1960) and Hayes (2003).

Edited by: M. Hoppema 


\section{References}

Aaboe, S. and Nøst, O. A.: A diagnostic model of he Nordic Seas and the Arctic Ocean circulation: Quantifying the effects of a variable bottom density along a sloping topography, J. Phys. Oceanogr., 38, 2685-2703, doi:10.1175/2008JPO3862.1, 2008.

Aagaard, K. and Coachman, L. K.: Toward an ice-free Arctic Ocean, Eos, 56, 484-486, 1975.

Aagaard, K. and Greisman, P.: Towards a new mass and heat budget for the Arctic Ocean, J. Geophys. Res., 80, 3821-3827, 1975.

Aagaard, K., Darnall, C., and Greisman, P.: Year-long measurements in the Greenland-Spitsbergen passage, Deep-Sea Res., 20, 743-746, 1973.

Aagaard, K., Coachman, L. K., and Carmack, E. C.: On the halocline of the Arctic Ocean, Deep-Sea Res., 28, 529-545, 1981.

Aagaard, K., Swift, J. H., and Carmack, E. C.: Thermohaline circulation in the Arctic Mediterranean Seas, J. Geophys. Res., 90, 4833-4846, 1985.

Anderson, L. G., Björk, G., Holby, O., Jones, E. P., Kattner, G., Koltermann, K.-P., Liljeblad, B., Lindegren, R., Rudels, B., and Swift, J. H.: Water masses and circulation in the Eurasian Basin: Results from the Oden 91 Expedition, J. Geophys. Res., 99, 3273-3283, 1994.

Björk, G. and Winsor, P.: The deep waters of the Eurasian Basin, Arctic Ocean: geothermal heat flow, mixing and renewal, DeepSea Res. I, 53, 1253-1271, 2006.

Björk, G., Jakobsson, M., Rudels, B., Swift, J. H., Anderson, L. G., Darby, D. A., Backman, J., Coakley, B., Winsor, P., Polyak, L., and Edwards, M.: Bathymetry and deep-water exchange across the central Lomonosov Ridge at $88^{\circ}-89^{\circ} \mathrm{N}$, Deep-Sea Res. I, 54, 1197-1208, doi:10.1016/j.dsr.2007.05.010, 2007.

Carmack, E. C., Macdonald, R. W., Perkin, R. G., and McLaughlin, F. A.: Evidence for warming of Atlantic water in the southern Canadian Basin, Geophys. Res. Lett., 22, 1961-1964, 1995.

Coachman, L. K. and Aagaard, K.: Transports through Bering Strait: Annual and interannual variability, J. Geophys. Res., 93, 15535-15539, 1988.

Coachman, L. K. and Barnes, C. A.: The contribution of Bering Sea water to the Arctic Ocean, Arctic, 14, 147-161, 1961.

Coachman, L. K. and Barnes, C. A.: The movement of Atlantic water in the Arctic Ocean, Arctic, 16, 8-16, 1963.

Dickson, R. R., Osborn, T. J., Hurell, J. W., Meincke, J., Blindheim, J., Ådlandsvik, B., Vinje, T., Alekseev, G., and Maslowski, W.: The Arctic Ocean response to the North Atlantic Oscillation, J. Climate, 13, 2671-2696, 2000.

Dickson, R., Rudels, B., Dye, S., Karcher, M., Meincke, J., and Yashayaev, I.: Current estimates of freshwater flux through the Arctic and Subarctic seas, Prog. Oceanogr., 73, 210-230, doi:10.1016/j.pocean.2006.12.003, 2007.

Ekman, V. W.: On the influence of earth's rotation on ocean currents. Arkiv för matematik, astronomi och fysik 2(11), 1905.

Foldvik, A., Aagaard, K., and Törresen, T.: On the velocity field of the East Greenland Current, Deep-Sea Res., 35, 1335-1354, 1988.

Gammelsrød, T., Leikvin, Ø., Lien, V., Budgell, W. P., Loeng, H., and Maslowski, W.: Mass and heat transports in the NE Barents Sea: Observations and models, J. Mar. Syst., 75, 56-69, 2009.

Gill, A. E.: Atmosphere-Ocean Dynamics, Academic Press, London, 662 pp., 1982.
Hayes, D.: Historical Atlas of the Arctic, Univ. Wash. Press, Seattle, 208 pp., 2003.

Helland-Hansen, B.: Nogen hydrografiske metoder, Forh. Skandinaviske Naturf. Mote, Kristiania, p. 357, 1916.

Helland-Hansen, B. and Nansen, F.: The Norwegian Sea. Ist physical oceanography based upon the Norwegian researches 19001904. Rep. on Norw. Fishery and Marine Investigations II(1), Kristiania, 1909.

Hunkins, K. and Whitehead, J. A.: Laboratory simulation of exchange through Fram Strait, J. Geophys. Res., 97, 11299-11321, 1992.

Jackson, J. M., Carmack, E. C., McLaughlin, F. A., Allen, S. E., and Ingram, R. G.: Identification, characterization, and change of the near-surface temperature maximum in the Canada basin, 1993-2008, J. Geophys. Res., 115, C05021, doi:10.1029/2009JC005265, 2010.

Jakobsson, M., Macnab, R., Mayer, L., Anderson, R., Edwards, M., Hatzky, J., Schenke, H. W., and Johnson, P.: An improved bathymetric portrayal of the Arctic Ocean: Implications for ocean modelling and geological, geophysical and oceanographic analyses, Geophys. Res. Lett., 35, L07602, doi:10.1029/2008GL033520, 2008.

Jones, E. P. and Anderson, L. G.: On the Origin of the Chemical Properties of the Arctic Ocean Halocline, J. Geophys. Res., 91, 10759-10767, 1986.

Jones, E. P., Rudels, B., and Anderson, L. G.: Deep Waters of the Arctic Ocean: Origins and Circulation, Deep-Sea Res., 42, 737760, 1995.

Kato, H. and Phillips, O. M.: On the penetration of a turbulent layer into a stratified fluid, J. Fluid Mech., 37, 643-655, 1969.

Kikuchi, T., Hatakeyama, K., and Morison, J. H.: Distribution of convective lower halocline water in the eastern Arctic Ocean, J. Geophys. Res., 109, C120301, doi:10.1029/2003JC002223, 2004.

Kikuchi, T., Inoue, J., and Morison, J. H.: Temperature differences across the Lomonosov Ridge: Implication for the Atlantic Water circulation in the Arctic Ocean, Geophys. Res. Lett., 32, L20604, doi:10.1029/2005GL023982, 2005.

Knipowitsch, N.: Hydrologische Untersuchungen im Europäischen Eismeer, Annalen der Hydrographie and Maritimen Meteorologie, Sonderabdruck, 62 pp., 1905.

Knudsen, M.: Ein hydrographischer Lehrsatz, Annalen der Hydrographie and Maritimen Meteorologie, 28, 316-320, 1900.

Kwok, R., Farrell, S., Forsberg, R., Giles, K., Laxon, S., McAdo, D., Morison, J., Padman, L., Peralta-Ferriz, C., Proshutinsky, A., and Steele, M.: Combining satellite altimetry, time-variable gravity, and bottom pressure observations to understand the Arctic Ocean: A transformative opportunity, OceanObs' 09, 21-25 September, 2009, Venice, Italy, 12 pp., 2009.

Laktionov, A.: Nordpolen, Förlaget för litteratur på främmande språk, Moskva, 522 pp., 1960.

Martinson, D. G. and Steele, M.: Future of the Arctic Sea Ice Cover: Implications of an Antarctic Analog, Geophys. Res. Lett., 28, 307-310, 2001.

McLaughlin, F. A., Carmack, E. C., Williams, W. J., Zimmermann, S., Shimada, K., and Itoh, M.: Joint effects of boundary currents and thermohaline intrusions on the warming of Atlantic water in the Canada Basin, 1993-2007, J. Geophys. Res., 114, C00A12, doi:10.1029/2008JC005001, 2009. 
Morison, J. H., Steele, M., and Anderson, R.: Hydrography of the upper Arctic Ocean measured form the nuclear submarine USS Pargo, Deep-Sea Res. I, 45, 15-38, 1998.

Morison, J., Kwok, R., Peralta-Ferriz, C., Alkire, M., Rigor, I., Andersen, R., and Steele, M.: Changing Arctic Ocean freshwater pathways, Nature, 481, 66-70, doi:10.1038/nature10705, 2012.

Nansen, F.: Oceanography of the North Polar Basin, The Norwegian North Polar Expedition 1893-1896, Scientific Results (9), 427 pp., 1902.

Nansen, F.: Northern Waters, Captain Roald Amundsen's oceanographic observations in the Arctic Seas in 1901, VidenskabSelskabets Skrifter 1. Matematisk-Naturvidenskabelig Klasse 1, Kristiania, 1-145, 1906.

Nansen, F.: Spitsbergen Waters. Videnskabs-selskabets skrifter I. Matematisk-Naturvidenskabelig klasse I(3), 145 pp., 1915.

Nazarenko, L., Holloway, G., and Tausnev, N.: Dynamics of transport of "Atlantic signature" in the Arctic Ocean, J. Geophys. Res., 103, 31003-31105, 1998.

Newton, J. L. and Coachman, L. K.: Atlantic water circulation in the Canada Basin, Arctic, 27, 297-303, 1974.

Nøst, O. A. and Isachsen, P. E.: The large-scale time-mean circulation in the Nordic Seas and the Arctic Ocean estimated from simplified dynamics, J. Mar. Res., 61, 175-210, 2003

Petermann, A.: Der Nordpol und Südpol, die Wichtigkeit ihrer Erforschung in geographischer und kulturhistorischer Beziehung, Mit Bemerkungen über die Strömungen der Polar-Meere. Pet. Mitt, 146-160, Gotha, 1865.

Polyakov, I. V., Beszczynska-Möller, A., Carmack, E., Dmitrenko, I., Fahrbach, E., Frolov, I., Gerdes, R., Hansen, E., Holfort, J., Ivanov, V., Johnson, M., Karcher, M., Kauker, F., Morison, J., Orvik, K., Schauer, U., Simmons, H., Skagseth, Ø., Sokolov, V., Steele, M., Timokhov, L., Walsh, D., and Walsh, J.: One more step towards a warmer Arctic, Geophys. Res. Lett., 32, L17605, doi:10.1029/2005GL023740, 2005.

Polyakov, I. V., Alekseev, V. A., Ashik, I. M., Bacon, S. Beszczynska-Möller, A., Dmitrenko, I., Fortier, L., Gascard, J.C., Hansen, E., Hölemann, J., Ivanov, V. V., Kikuchi, T., Krillov, S., Lenn, Y.-D., Piechura, J., Repina, I., Timokhov, L. A., Walczowski, W., and Woodgate, R.: Fate of the early-2000s Arctic warm pulse, B. Am. Meteor. Soc., 92, 561-566, 2011.

Polyakov, I. V., Walsh, J. E., and Kwok, R: Recent changes in the Arctic multiyear sea ice coverage and its likely causes, B. Am. Meteor. Soc., 96, 145-151, doi:10.1175/BAMS-D-11-00070.1, 2012.

Proshutinsky, A. and Johnson, M. A.: Two circulation regimes of the wind-driven Arctic Ocean, J. Geophys. Res., 102, 1249312514, doi:10.1029/97JC00738, 1997.

Proshutinsky, A., Krishfield, R., Timmermanns, M.-L., Toole, J., Carmack, E., McLaughlin, F. Williams, W. J., Zimmermann, S., Itoh, M., and Shimada, K.: Beaufort Gyre freshwater reservoir: State and variability from observations, J. Geophys. Res., 114, C00A10, 61-85, doi:10.1029/2008JC005104, 2010.

Quadfasel, D., Sy, A., Wells, D., and Tunik,: A. A warming of the Arctic, Nature, 359, p. 385, 1991.

Rabe, B., Karcher, M., Schauer, U., Toole, J. M., Krichfield, R. A., Pisarev, S., Kauker, F., Gerdes, R., and Kikuchi, T.: An assessment of Arctic Ocean freshwater content changes from 1990s to the 2006-2008 period, Deep-Sea Res. I, 58, 175-185, doi:10.1016/j.dsr.2010.12.002, 2010.
Riis-Carstensen, E.: The "Godthaab" expedition 1928, The hydrographic work and material, Meddeleser om Grönland 78(3), 101 pp., 1936.

Rudels, B.: The outflow of Polar Water through the Arctic Archipelago and the oceanographic conditions in Baffin Bay, Polar Res., 4, 161-180, 1986a.

Rudels, B.: The $\Theta-S$ relations in the northern seas: Implications for the deep circulation, Polar Res., 4, 133-159, 1986 b.

Rudels, B.: On the mass balance of the Polar Ocean, with special emphasis on the Fram Strait, Norsk Polarinstitutt Skrifter 188, Oslo, 53 pp., 1987.

Rudels, B.: The formation of Polar Surface Water, the ice export and the exchanges through the Fram Strait, Prog. Oceanogr., 22, 205-248, 1989.

Rudels, B.: The thermohaline circulation of the Arctic Ocean and the Greenland Sea, Philos. T. Roy. Soc. Lond. A, 352, 287-299, 1995.

Rudels, B.: Arctic Ocean Circulation. In Encyclopedia of Ocean Sciences, edited by: Steele, J. H., Turekian, K. K., and Thorpe, S. A., Academic Press, San Diego, 211-225, doi:016/B978012374473-9.00601-9, 2009.

Rudels, B.: Constraints on exchanges in the Arctic Mediterranean - Do they exist and can they be of use?, Tellus, 62A, 109-122, 2010.

Rudels, B.: Volume and freshwater transports through the Canadian Arcti Archipelago - Baffin Bay system, J. Geophys. Res., 116, C00D10, doi:10.1029/2011JC007019, 2011.

Rudels, B. and Quadfasel, D.: Convection and deep water formation in the Arctic Ocean - Greenland Sea system, J. Marine. Syst., 2, 435-450, 1991.

Rudels, B., Jones, E. P., Anderson, L. G., and Kattner, G... On the intermediate depth waters of the Arctic Ocean, in: The role of the Polar Oceans in Shaping the Global Climate, edited by: Johannessen, O. M., Muench, R. D., and Overland, J. E., American Geophysical Union, Washington DC, 33-46, 1994.

Rudels, B., Anderson, L. G., and Jones, E. P.: Formation and evolution of the surface mixed layer and the halocline of the Arctic Ocean, J. Geophys. Res., 101, 8807-8821, 1996.

Rudels, B., Friedrich, H. J., Hainbucher, D., and Lohmann, G.: On the parameterisation of oceanic sensible heat loss to the atmosphere and to ice in an ice-covered mixed layer in winter, DeepSea Res. II, 46, 1385-1425, 1999a.

Rudels, B., Friedrich, H. J., and Quadfasel, D.: The Arctic Circumpolar Boundary Current, Deep-Sea Res. II, 46, 1023-1062, 1999b.

Rudels, B., Muench, R. D., Gunn, J., Schauer, U., and Friedrich, H. J.: Evolution of the Arctic Ocean boundary current north of the Siberian shelves, J. Marine Syst., 25, 77-99, 2000.

Rudels, B., Jones, E. P., Schauer, U., and Eriksson, P.: Atlantic sources of the Arctic Ocean surface and halocline waters, Polar Res., 23, 181-208, 2004.

Rudels, B., Marnela, M., and Eriksson, P.: Constraints on Estimating Mass, Heat and Freshwater Transport in the Arctic Ocean: An Exercise, in: Arctic-Subarctic Ocean Fluxes, edited by: Dickson, R. R., Meincke, J., and Rhines, P., 315-341, Springer, Dordrecht, 2008.

Rudels, B., Anderson, L., Eriksson, P., Fahrbach, E., Jokobsson, M., Jones, E. P., Melling, H., Prinsenberg, S., Schauer, U., and Yao, T.: Observation in the Ocean. Chapter 4 in: Arctic Climate 
Change: The ACSYS decade and beyond, edited by: Lemke, P. and Jacobi, H.-W., 117-198, Springer, Heidelberg, 2011.

Sandström, J. W. and Helland-Hansen, B.: Über die Berechnung von Meeresströmungen, Rep. Norwegian Fish. Marine Invest., 2(4), 43 pp., 1903.

Schauer, U., Muench, R. D., Rudels, B., and Timokhov, L.: Impact of eastern Arctic Shelf water on the Nansen Basin intermediate layers, J. Geophys. Res., 102, 3371-3382, 1997.

Schauer, U., Beszczynska-Möller, A., Walczowski, W., Fahrbach, E., Piechura, J., and Hansen, E.: Variation of measured heat flow through the Fram Strait between 1997-2006, in: ArcticSubarctic Ocean Fluxes, Dickson, R. R., Meincke, J., and Rhines, P., 65-85, Springer, Dordrecht, 2008.

Schlitzer, R.: Ocean Data View, available at: http://odv.awi.de, 2012

Serreze, M. C., Barrett, A., Slater, A. J., Woodgate, R. A., Aagaard, K., Steele, M., Moritz, R., Meredith, M., and Lee, C.: The large-scale freshwater cycle in the Arctic, J Geophys. Res., 111, C11010, doi:10.1029/2005JC003424, 2006.

Shimada, K., McLaughlin, F. A., Carmack, E. C., Proshutinsky, A., Nishino, S., and Itoh, M.: Penetration of the 1990s warm temperature anomaly of the Atlantic Water in the Canada basin, Geophys. Res. Lett., 31, L20301, doi:10.1029/2004GL020860, 2004.

Shimada, K., Itoh, M., Nishino, S., McLaughlin, F. A., Carmack, E., and Proshutinsky, A.: Halocline structure in the Canada Basin of theARctic Ocean, Geophys. Res. Lett., 32, L03605, doi:10.1029/2004GL021358, 2005.

Smethie, W. M., Schlosser, P., and Bönisch, G.: Renewal and circulation of intermediate waters in the Canadian Basin observed on the SCICEX 96 cruise, J. Geophys. Res., 105, 1105-1121, 2000.

Smith, J. N., Ellis, K. M., and Boyd, T.: Circulation features in the central Arctic Ocean revealed by nuclear fuel reprocessing tracers from Scientific Ice Expeditions 1995 and 1996, J. Geophys. Res., 104, 29663-29667, 1999.
Stigebrandt, A.: A model for the thickness and salinity of the upper layers of the Arctic Ocean and the relation between the ice thickness and some external parameters, J. Phys. Oceanogr., 11, 1407-1422, 1981.

Stigebrandt, A.: The North Pacific: A global-scale estuary, J. Phys. Oceanogr., 14, 464-470, 1984.

Swift, J. H., Jones, E. P., Carmack, E. C., Hingston, M., Macdonald, R. W., McLaughlin, F. A., and Perkin, R. G.: Waters of the Makarov and Canada Basins, Deep-Sea Res. II, 44, 1503-1529, 1997.

Timmermanns, M.-L. and Garrett, C.: Evolution of the deep water in the Canadian Basin in the Arctic Ocean, J. Phys. Oceanogr., 36, 866-874, 2006.

Timmermanns, M.-L., Garrett, C., and Carmack, E.: The thermohaline structure and evolution of the deep waters in the Canada Basin, Arctic Ocean, Deep-Sea Res. I, 50, 1305-1321, doi:10.1016/S0967-0637(03)00125-0, 2003.

Timofeyev, V. T.: Water masses of the Arctic basin, Gidromet. Izdat., Leningrad, 1960.

Wadhams, P., Gill, A., and Linden, P. F.: Transect by submarine of the East Greenland Front, Deep-Sea Res., A, 26, 1311-1327, 1979.

Walsh, D. and Carmack, E. C.: The nested structure of Arctic thermohaline intrusions, Ocean Modell., 5, 267-289, 2003.

Werenskiold, W.: Coastal Currents, Geophysical publications, 10(13), Oslo, 1935.

Weyl, P. K.: The role of the oceans in climate change, Meteor. Mon., 8, 37-62, 1968.

Wüst, G.: Relief und Bodenwasser im Nordpolarbecken, Zeitschrift der Gesellschaft für Erdkunde zu Berlin, 5/6, 163-180, 1941. 